\title{
Aridity assessment within southern Romania and northern Bulgaria
}

\section{Procjena aridnosti za južnu Rumunjsku i sjevernu Bugarsku}

Drought and aridity assessments have become issues of global importance as temperatures increase, precipitation amounts fluctuate, and socio-economic demands rise. Southern Romania and northern Bulgaria are the most intensively agriculturally used regions in both countries. Thus, widely-used aridity indices have been applied to the combined area, which generally highlighted a similar territorial pattern. The areas most affected by aridity include the Danube Delta, the Black Sea shore, and part of the Danube Alluvial Plain (according to the De Martonne Aridity Index, Gaussen correlation, and Selyaninov's hydrothermal coefficient). The Pearson correlation coefficient highlighted significant statistical correlations among the applied indices, except for the Pinna Combinative Index, which had correlation values between $0.69\left(\mathrm{I}_{\mathrm{p}} / \mathrm{IE}\right)$ and $0.74\left(\mathrm{I}_{\mathrm{p}} / \mathrm{HTC}\right)$.

Key words: aridity indices, aridity assessment, southern Romania, northern Bulgaria
Zbog porasta temperature, promjenljivosti količine padalina te sve većega pritiska socioekonomskih čimbenika procjene suša i aridnosti postale su važna pitanja na globalnoj razini. Južna Rumunjska i sjeverna Bugarska u objema su zemljama najintenzivnije iskorištavana poljoprivredna područja. Najčešće korišteni pokazatelji aridnosti pokazali su sličnu prostornu raspodjelu. Područja najviše zahvaćena aridnošću obuhvaćaju deltu Dunava, crnomorsku obalu i dio naplavne ravni Dunava (De Martonneov indeks aridnosti, Gaussenova korelacija, Seljaninovljev hidrotermalni koeficijent). Pearsonov koeficijent korelacije pokazao je značajne statističke korelacije među primijenjenim indeksima, osim za Pinnin kombinirani indeks, čije su vrijednosti korelacije bile između 0,69 (I/ IE) i 0,74 (I/HTC).

Ključne riječi: pokazatelji aridnosti, procjena aridnosti, južna Rumunjska, sjeverna Bugarska 


\section{Introduction}

Scientific research has repeatedly emphasised the increasing general trend in air temperature at the global scale and in many regions of the world. According to IPCC (2014), the increase between the average of the 1850-1900 period and the average of the 2003-2012 period is $0.78^{\circ} \mathrm{C}$. Despite the reduction in the surface warming trend during the 1998-2012 period, in comparison to 1951-2012, all assessed emission scenarios have projected an increase in surface temperature over the $21^{\text {st }}$ century. At the same time, a general tendency of increase in precipitation amounts during the present century, in middle and high latitudes of the Northern Hemisphere, has been established. Conversely, the results from the Coupled Model Intercomparison Project Phase 5 (CMIP5) showed a projected decrease in precipitation in Southern Europe, including Romania and Bulgaria, of about $10-20 \%$ for the 2081-2100 period, in relation to 1986-2005 (IPCC, 2014). On the background of global climate change, it is important to study aridity conditions at the regional level, together with extreme events such as heat waves, heavy precipitation, floods, and drought, as these could have considerable effect on the development of agriculture and food production.

Unlike drought, a temporary phenomenon, aridity is a permanent feature of the climate and is restricted to low rainfall areas (Wilhite, 2000). Aridity is mainly the result of large-scale, persistent, atmospheric and oceanic circulation patterns or regional geography and topography (Maliva and Missimer, 2012). One of the most-cited maps of distribution of non-polar dry areas (Desserts of the World - USGS, 2017), created on the basis of the Thornthwaite classification, showed that aridity is widely spread in tropical and subtropical latitudes and also in the temperate zones of Asia and North and South America. According to the Thornthwaite and Köppen classifications, in Europe, aridity is characteristic only for some parts of the Iberian Peninsula. In recent years, the interest in investigating aridity and climate water deficit as important climate features in the Mediterranean region and South-Eastern and Central Europe, has increased, as shown by the following papers: Andrade and Corte-Real (2016), Chendeş et al. (2010), Cheval et al. (2016), Hrnjak et al. (2014), Kenawy et al. (2016), Nikolova and Mochurova (2012), Nistor (2016) and Rego and Rocha (2014).
Uvod

Brojna znanstvena istraživanja upućuju na opći trend porasta temperature zraka na globalnoj razini, kao i u brojnim područjima svijeta. Prema IPCC-u (2014) porast srednjaka razdoblja 1850. - 1900. u odnosu na razdoblje 2003. - 2012. iznosi $0,78{ }^{\circ} \mathrm{C}$. Usprkos smanjenju trenda zagrijavanja u razdoblju 1998. - 2012. u usporedbi s 1951. - 2012. sve procjene emisije stakleničkih plinova predviđale su povećanje površinske temperature tijekom 21. stoljeća. Istodobno je u ovom stoljeću utvrđeno općenito povećanje količine padalina u umjerenim i visokim geografskim širinama na sjevernoj hemisferi. Suprotno tomu, rezultati Pete projektne faze združenih globalnih modela Coupled Model Intercomparison Project Phase 5, (CMIP5) predviđaju smanjenje količine padalina u južnoj Europi, uključujući Rumunjsku i Bugarsku, za oko 10 - $20 \%$ u razdoblju 2081. -2100. u odnosu na razdoblje 1986. - 2005. (IPCC, 2014). U okviru globalnih klimatskih promjena vrlo je važno na regionalnoj razini istraživati čimbenike koji utječu na pojavu aridnosti, ali i ekstremne pojave poput toplinskih valova, obilnih padalina, poplava i suša jer oni mogu imati znatan utjecaj na poljoprivredu i proizvodnju hrane.

Za razliku od suše, koja je privremena pojava, aridnost je trajno obilježje klime i javlja se u u područjima s malom količinom padalina (Wilhite, 2000). Aridnost je većinom posljedica stalne cirkulacije oceana i atmosfere velikih razmjera te regionalnih čimbenika i reljefa (Maliva i Missimer, 2012). Jedna od najcitiranijih karata distribucije izvanpolarnih sušnih područja (Desserts of the World - USGS, 2017), koja se temelji na Thornthwaiteovoj klasifikaciji, pokazuje da je aridnost rasprostranjena u tropskim i suptropskim, ali i u umjerenim geografskim širinama u Aziji te u Sjevernoj i Južnoj Americi. Prema Thornthwaiteovoj i Köppenovoj klasifikaciji aridnost se u Europi javlja samo u nekim dijelovima Pirenejskoga poluotoka. Posljednjih se godina izrazito povećalo zanimanje za istraživanje aridnosti i klimatski uvjetovane nestašice vode kao važnih klimatskih obilježja Sredozemlja te jugoistočne i središnje Europe, što potvrđuju i sljedeći radovi: Andrade i Corte-Real (2016), Chendeş i dr. (2010), Cheval i dr. (2016), Hrnjak i dr. (2014), Kenawy i dr. (2016), Nikolova i Mochurova (2012), Nistor (2016) i Rego i Rocha (2014). 
Many recent publications have also analysed aridity conditions in Bulgaria and Romania. Topliisky (2006) pointed out that aridity is a characteristic of climate for approximately two-thirds of the territory of Bulgaria in the lowland and plain hypsometric areas, and it is expressed mainly in the June-October period (September). On the basis of the Gaussen-Bagnouls classification method, Nikolova and Mochurova (2012) identified arid conditions in the south of Bulgaria for the July-September period. According to Dragotă et al. (2011), Southern Oltenia is one of the Romanian regions which is most affected by aridity and drought. The aridification process in southern Romania was detected and analysed by Peptenatu et al. (2013), Păltineanu et al. (2007), by Tiscovschi et al. (2013) in Dobroudja, by Pelin (2016) in eastern Romania (Moldavia Plain), and by Croitoru et al. (2013) in extra-Carpathian regions.

This paper aims to evaluate the aridity conditions in southern Romania and northern Bulgaria in terms of their territorial and temporal occurrence. Therefore, calculations were made using a range of indices such as: De Martonne Aridity Index; Pinna Combinative Index; Gaussen correlation between precipitation and temperatures; Emberger index; and Selyaninov's hydrothermal coefficient.

The study of aridity in southern Romania and northern Bulgaria is important because this large and mainly plain territory is characterised by developed agriculture and food production. Several million hectares are cultivated with wheat and maize, as main crops, but also with sunflower, barley, and rape. At the same time, vegetables represent an important crop in the proximity of the main settlements. Taking into account the fact that most of these surfaces are not irrigated, they depend greatly on the climatic conditions in the region.

\section{Data and methods}

The indices were calculated based on mean monthly temperature and precipitation data from 26 meteorological stations located within the regions of interest (Tab. 1, Fig. 1), mainly for the 1961-2015 period (except for Vânju Mare, Romania, for which data only runs to 2002). Consequently, in the case of Vânju Mare station, aridity was assessed only for the aforementioned period, and the obtained results were taken into account only for the elaboration of the maps.
Brojni recentni radovi analiziraju aridnost $\mathrm{u}$ Bugarskoj i Rumunjskoj. Topliisky (2006) ističe da se aridnost javlja na otprilike dvije trećine bugarskoga teritorija u nizinskim i zaravnjenim područjima većinom u razdoblju od lipnja do listopada (rujna). Na temelju Gaussen-Bagnoulsove klasifikacije Nikolova i Mochurova (2012) odredile su pojavnost aridnosti na jugu Bugarske za razdoblje između srpnja i rujna. Prema Dragotă i dr. (2011) južna Oltenija jedna je od rumunjskih regija najviše pogođenih aridnošću i sušom. Proces aridifikacije u južnoj Rumunjskoj opazili su i analizirali Peptenatu i dr. (2013), Păltineanu i dr. (2007), Tiscovschi i dr. (2013) u Dobroudži, Pelin (2016) u istočnoj Rumunjskoj (Moldavska ravnica); Croitoru i dr. (2013) u izvankarpatskim regijama itd.

Rad se bavi procjenom aridnosti u južnoj $\mathrm{Ru}-$ munjskoj i sjevernoj Bugarskoj te njezinom prostornom i vremenskom pojavnošću. U tu svrhu izračunati su pokazatelji aridnosti: De Martonneov indeks aridnosti, Pinnin kombinirani indeks, Gaussenova korelacija između padalina i temperature, Embergerov indeks i Seljaninovljev hidrotermalni koeficijent.

Istraživanje aridnosti u južnoj Rumunjskoj i sjevernoj Bugarskoj važno je zbog toga što to prostrano i uglavnom ravničarsko područje obilježavaju razvijena poljoprivreda i proizvodnja hrane. Na nekoliko se milijuna hektara kao glavne kulture uzgajaju pšenica i kukuruz, ali i suncokret, ječam i uljana repica. U blizini većih naselja važan je uzgoj povrća. S obzirom na to da se većina tih površina ne navodnjava, prinosi uvelike ovise o klimatskim uvjetima.

\section{Podaci i metode}

Pokazatelji su izračunani na temelju podataka o srednjim mjesečnim temperaturama i padalinama iz 26 meteoroloških postaja unutar istraživanoga područja (tab. 1, sl. 1) za razdoblje 1961. - 2015., osim za postaju Vânju Mare u Rumunjskoj, za koju podaci postoje do 2002. godine. Za tu su postaju pokazatelji aridnosti izračunani za razdoblje do te godine, a dobiveni rezultati korišteni su samo za razradu karata.
A. Ş Vlăduţ

N. Nikolova

M. Licurici

Aridity assessment within southern

Romania and northern Bulgaria

Procjena aridnosti za južnu Rumunjsku i sjevernu Bugarsku 
HRVATSKI

GEOGRAFSKI

GLASNIK

$79 / 2,5-26(2017$.

Tab. 1 Geographical coordinates of the meteorological stations (from west to east in the study area)

Tab. 1. Geografske koordinate meteoroloških postaja (od zapada prema istoku istraživanoga područja)

\begin{tabular}{|c|c|c|c|c|}
\hline $\begin{array}{l}\text { No. } \\
\text { / Br. }\end{array}$ & $\begin{array}{l}\text { Station } \\
\text { / Postaja }\end{array}$ & $\begin{array}{c}\text { Altitude }(\mathbf{m}) \\
\text { / Nadmorska visina }(\mathrm{m})\end{array}$ & $\begin{array}{c}\text { Latitude } \\
\text { / Geografska širina }\end{array}$ & $\begin{array}{c}\text { Longitude } \\
\text { / Geografska dužina }\end{array}$ \\
\hline 1 & D.T. Severin & 77 & $44^{\circ} 37^{\prime}$ & $22^{\circ} 37^{\prime}$ \\
\hline 2 & Vidin & 31 & $43^{\circ} 59^{\prime}$ & $22^{\circ} 51^{\prime}$ \\
\hline 3 & Vânju Mare & 86 & $44^{\circ} 26^{\prime}$ & $22^{\circ} 51^{\prime}$ \\
\hline 4 & Calafat & 61 & $43^{\circ} 59^{\prime}$ & $22^{\circ} 57^{\prime}$ \\
\hline 5 & Lom & 32 & $43^{\circ} 49^{\prime}$ & $23^{\circ} 13^{\prime}$ \\
\hline 6 & Băileşti & 57 & $44^{\circ} 01^{\prime}$ & $23^{\circ} 20^{\prime}$ \\
\hline 7 & Bechet & 36 & $43^{\circ} 47^{\prime}$ & $23^{\circ} 57^{\prime}$ \\
\hline 8 & Craiova & 192 & $44^{\circ} 13^{\prime}$ & $23^{\circ} 52^{\prime}$ \\
\hline 9 & Oriahovo & 29 & $43^{\circ} 43^{\prime}$ & $23^{\circ} 58^{\prime}$ \\
\hline 10 & Kneja & 117 & $43^{\circ} 30^{\prime}$ & $24^{\circ} 05^{\prime}$ \\
\hline 11 & Caracal & 106 & $44^{\circ} 06^{\prime}$ & $24^{\circ} 22^{\prime}$ \\
\hline 12 & Pleven & 160 & $43^{\circ} 24^{\prime}$ & $24^{\circ} 37^{\prime}$ \\
\hline 13 & Pitești & 316 & $44^{\circ} 50^{\prime}$ & $24^{\circ} 51^{\prime}$ \\
\hline 14 & Roşiorii de Vede & 102 & $44^{\circ} 06^{\prime}$ & $24^{\circ} 58^{\prime}$ \\
\hline 15 & Russe & 36 & $43^{\circ} 51^{\prime}$ & $25^{\circ} 57^{\prime}$ \\
\hline 16 & Bucureşti Băneasa & 90 & $44^{\circ} 31^{\prime}$ & $26^{\circ} 04^{\prime}$ \\
\hline 17 & Razgrad & 346 & $43^{\circ} 33^{\prime}$ & $26^{\circ} 30^{\prime}$ \\
\hline 18 & Buzău & 19 & $45^{\circ} 07^{\prime}$ & $26^{\circ} 51^{\prime}$ \\
\hline 19 & Shumen & 218 & $43^{\circ} 16^{\prime}$ & $26^{\circ} 11^{\prime}$ \\
\hline 20 & Focșani & 57 & $45^{\circ} 41^{\prime}$ & $27^{\circ} 56^{\prime}$ \\
\hline 21 & Călăraşi & 90 & $44^{\circ} 12^{\prime}$ & $27^{\circ} 19^{\prime}$ \\
\hline 22 & Varna & 39 & $43^{\circ} 12^{\prime}$ & $27^{\circ} 57^{\prime}$ \\
\hline 23 & Galaţi & 71 & $45^{\circ} 30^{\prime}$ & $28^{\circ} 01^{\prime}$ \\
\hline 24 & Constanţa & 13 & $44^{\circ} 13^{\prime}$ & $28^{\circ} 37^{\prime}$ \\
\hline 25 & Tulcea & 4 & $45^{\circ} 10^{\prime}$ & $28^{\circ} 49^{\prime}$ \\
\hline 26 & Sulina & 3 & $45^{\circ} 10^{\prime}$ & $29^{\circ} 43^{\prime}$ \\
\hline
\end{tabular}




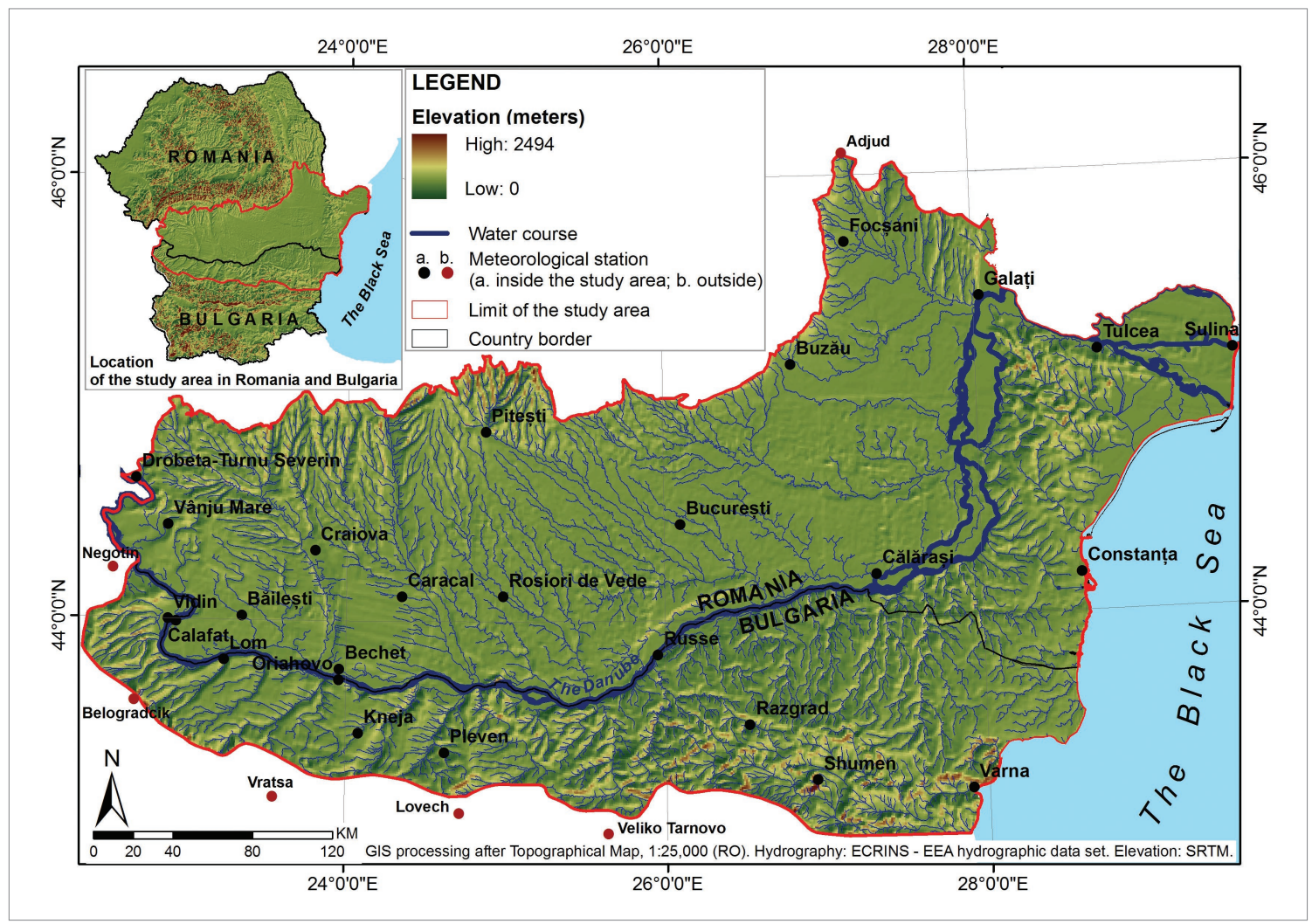

A. Ş Vlăduţ

N. Nikolova

M. Licurici

Aridity assessment within southern

Romania and northern Bulgaria

Procjena aridnosti za južnu Rumunjsku i sjevernu Bugarsku

Fig. 1 Study area and location of the meteorological stations

SI. 1. Istraživano područje i položaj meteoroloških postaja

For the maps rendering the spatial distribution of the aridity indices, certain stations situated in the immediate proximity of the plain region (Adjud for Romania; Belogradchik, Vratsa, Lovech and Veliko Tarnovo for Bulgaria; Nis, Bor, and Negotin for Serbia) were also taken into account. Climatic data (European Climate Assessment \& Dataset, 2017) for the Romanian territory were obtained from Klein Tank et al. (2002), the exceptions were Bechet, Calafat, Băileşti, Caracal, Vânju Mare, for which data were partly provided by the National Meteorological Administration (up to 2009), taken from the annual reports of the Environmental Protection Agency and Climate - Climate data (Global climate data, 2017), for Piteşti, Foç̧ani, and Adjud mean values of temperature and precipitation data were obtained from Climate data for cities worldwide (2017).

The data for air temperature and precipitation amounts for the Bulgarian territory were taken from the annual yearbooks and bulletins of the National Institute of Meteorology and Hydrology, as well as from the Statistical yearbook of the National Statistical Institute of
Za izradu karata s prostornom raspodjelom indeksa aridnosti u obzir su uzete i neke postaje u neposrednoj blizini istraživanoga područja (Adjud za Rumunjsku; Belogradčik, Vraca, Loveč i Veliko Trnovo za Bugarsku; Niš, Bor i Negotin za Srbiju). Klimatski podaci (European Climate Assessment \& Dataset, 2017) za područje Rumunjske preuzeti su iz Klein Tank i dr. (2002), osim za Bechet, Calafat, Băileşti, Caracal, Vânju Mare, čiji su podaci djelomice dobiveni od Državne meteorološke uprave (do 2009.), a koji su preuzeti iz godišnjih izvješća Agencije za zaštitu okoliša i s internetskog izvora (Global climate data, 2017), za Piteşti, Focşani i Adjud srednje vrijednosti temperature i padalina preuzeti su s Climate data for cities worldwide (2017).

Podaci za temperaturu zraka i količinu padalina za postaje u Bugarskoj preuzeti su iz godišnjaka i biltena Državnoga instituta za meteorologiju i hidrologiju te statističkoga godišnjaka bugarskoga Državnoga statističkog ureda. Nedostajući podaci 
Bulgaria. The missing data were filled with information from specialised websites (i.e. European Climate Assessment and Dataset, 2017; Global climate data, 2017).

The spatial projection of the computed data was realised in a GIS environment. Thus, a complex geodatabase was created for this assessment; it comprised basic elements, such as the spatial locations of the used meteorological stations, as well as specialised data, such as the characteristic values for the analysed indices. Among the several spatial interpolation methods available for this study, the spatialisation of the mean values was conducted using the Spline Tension Method, readily integrated into ArcGIS Spatial Analyst Tools. Auxiliary geographical information concerning altitude was integrated into GIS using the digital elevation model (SRTM data).

The De Martonne Aridity Index, proposed by De Martonne (1926), was one of the first indices used in the assessment of aridity. Baltas (2007) used it for northern Greece, Coscarelli et al. (2004) for Southern Italy, Croitoru et al. (2013) for extra-Carpathian regions, Moteva et al. (2010) for Bulgaria, Sajjad and Shahzada (2014) for Pakistan, etc. At the annual level $\left(\mathrm{I}_{\mathrm{a}}\right)$, the index is calculated according to the following formula:

$$
I_{a}=\frac{P}{T+10}
$$

where $P=$ the annual amount of precipitation, $T$ $=$ the mean annual temperature, and $10=$ a coeffi cient that is added in order to obtain positive values. Consequently, if there is registered the increase of $\mathrm{I}_{\mathrm{a}}$ values and the temperature is constant, it indicates an increase in precipitation amounts. The thresholds and classification of $\mathrm{I}_{\mathrm{a}}$ values are rendered in Tab. 2 .

At the monthly level, the De Martonne Aridity Index $\left(\mathrm{I}_{\mathrm{m}}\right)$ is calculated by the following equation:

$$
I_{m}=\frac{12 P}{T+10}
$$

where $P$ and $T$ are the monthly mean values of precipitation and air temperature for the considered month. The classification of $\mathrm{I}_{\mathrm{m}}$ values are rendered in Tab. 3 . dopunjeni su onima sa specijaliziranih mrežnih stranica (i.e. European Climate Assessment and Dataset, 2017; Global climate data, 2017).

Rezultati rada prostorno su prikazani u GIS okružju. Tako je za potrebe ove procjene nastala složena baza geopodataka koja se sastoji od osnovnih elemenata poput prostornoga položaja korištenih meteoroloških postaja, ali i specijaliziranih podataka poput vrijednosti analiziranih indeksa. Od nekoliko raspoloživih metoda interpolacije u ovom je radu korištena metoda Spline Tension koja je dio ArcGIS-ovih alata za prostornu analizu. Dodatni geografski podaci koji se odnose na nadmorsku visinu u GIS su ugrađeni korištenjem digitalnoga modela reljefa (SRTM podaci).

De Martonneov indeks aridnosti jedan je od prvih pokazatelja korištenih za procjenu aridnosti, a predložio ga je De Martonne (1926). Primjerice, Baltas (2007) ga je iskoristio za sjevernu Grčku, Coscarelli i dr. (2004) za južnu Italiju, Croitoru i dr. (2013) za izvankarpatska područja, Moteva i dr. (2010) za Bugarsku, Sajjad i Shahzada (2014) za Pakistan itd. Na godišnjoj se razini ( $\left.\mathrm{I}_{\mathrm{a}}\right)$ indeks izračunava prema sljedećoj formuli:

$$
I_{a}=\frac{P}{T+10}
$$

gdje je $P$ - godišnja količina padalina, $T$ - srednja godišnja temperatura, 10 - koeficijent koji se dodaje kako bi se dobile pozitivne vrijednosti. Prema tome, ako je vrijednost $I_{a}$ porasla, a temperatura je konstantna, znači da je došlo do porasta količine padalina. Granične vrijednosti i klasifikacija I prikazani su u tab. 2.

$\mathrm{Na}$ mjesečnoj razini De Martonneov indeks aridnosti $\left(\mathrm{I}_{\mathrm{m}}\right)$ izračunava se formulom:

$$
I_{m}=\frac{12 P}{T+10}
$$

gdje su $P$ i $T$ srednje mjesečne vrijednosti padalina i temperature zraka za promatrani mjesec. $\mathrm{Kla}^{-}$ sifikacija vrijednosti $I_{m}$ navedena je u tab. 3 . 
Tab. 2 De Martonne index climatic classification

Tab. 2. Klasifikacija klima prema De Martonneovu indeksu

\begin{tabular}{|c|c|l|}
\hline $\mathbf{I}_{\mathbf{a}}$ & \multicolumn{1}{|c|}{$\begin{array}{c}\text { Precipitation } \\
\text { / Padaline }\end{array}$} & \multicolumn{1}{|c|}{$\begin{array}{c}\text { Climate classification } \\
\text { / Klimatska klasifikacija }\end{array}$} \\
\hline 10 & $<200$ & Dry / Suha \\
\hline $10-20$ & $200-400$ & Semi-dry / Polusuha \\
\hline $20-24$ & $400-500$ & Mediterranean / Sredozemna \\
\hline $24-28$ & $500-600$ & Semi-humid / Poluhumidna \\
\hline $28-35$ & $600-700$ & Humid / Humidna \\
\hline a. $35-55$ & $700-800$ & Very humid / Vrlo humidna \\
\hline b. $>55$ & $>800$ & Very humid / Vrlo humidna \\
\hline
\end{tabular}

A. Ş Vlăduţ

N. Nikolova

M. Licurici

Aridity assessment within southern

Romania and northern Bulgaria

Procjena aridnosti za južnu Rumunjsku i sjevernu Bugarsku

Source / lzvor: Baltas (2007)

Tab. 3 De Martonne index climatic classification

Tab. 3. Klasifikacija klima prema De Martonneovu indeksu

\begin{tabular}{|c|l|}
\hline $\mathbf{I}_{\mathbf{a}}$ & \multicolumn{1}{|c|}{$\begin{array}{l}\text { Climate classification } \\
\text { / Klimatska klasifikacija }\end{array}$} \\
\hline$<10$ & Dry or arid / Suha ili aridna \\
\hline $11-24$ & Semiarid / Semiaridna \\
\hline $24-30$ & Moderately arid / Umjereno aridna \\
\hline $30-35$ & Slightly humid / Neznatno humidna \\
\hline $35-40$ & Moderately humid / Umjereno humidna \\
\hline $40-50$ & Humid / Humidna \\
\hline $50-60$ & Very Humid / Vrlo humidna \\
\hline $60-187$ & Excessively humid / Iznimno humidna \\
\hline
\end{tabular}

Source / Izvor: Monthly de Martonne Aridity Index - NTUA, 2017

The Pinna Combinative Index $\left(\mathrm{I}_{\mathrm{p}}\right.$ ) was developed by Pinna (Zambakas, 1992, cited in Baltas, 2007) and uses the following equation:

$$
I_{p}=\frac{1}{2}\left(\frac{P}{T+10}+\frac{12 P_{d}^{\prime}}{T_{d}^{\prime}+10}\right)
$$

where $P$ and $T$ are the annual mean values of precipitation and air temperature and $P_{d}$ and $T_{d}{ }^{\prime}$ are the mean values of precipitation and air temperature of the driest month. If $I_{p}$ is less than 10 , the
Pinnin kombinirani indeks ( $\mathrm{I}_{\mathrm{p}}$ ) osmislio je Pinna (Zambakas, 1992, citirano u Baltas, 2007) i koristi sljedeću jednadžbu:

$$
I_{p}=\frac{1}{2}\left(\frac{P}{T+10}+\frac{12 P_{d}^{\prime}}{T_{d}^{\prime}+10}\right)
$$

gdje su $P$ i $T$ srednje godišnje vrijednosti količine padalina i temperature zraka, a $P_{d}^{\prime}$ i $T_{d}^{\prime}$ su srednje vrijednosti količine padalina i temperature zraka najsušega mjeseca. Ako je I manji od 10, kli- 
GEOGRAFSKI

GLASNIK

79/2,5-26 (2017.) climate is considered to be dry, between 10 and 20 to be semi-dry, and above 20 to be humid (Andrade and Corte-Real, 2016). It has mainly been applied in the Mediterranean region, Portugal (Andrade and Corte-Real, 2016), northern Greece (Baltas, 2007), and Turkey (Deniz et al., 2011). More recently, Croitoru et al. (2013) applied it for Romania (extra-Carpathian regions) and Cheval et al. (2016) applied it at the continental scale.

The Gaussen correlation between precipitation and temperatures is a graphical method of assessing climate patterns. Taking into account that Gaussen considered that a dry month is defined by the relation $\mathrm{P} / \mathrm{T}<2$, then the scale $20 \mathrm{~mm} \mathrm{P}$ corresponding to $10^{\circ} \mathrm{C}$ should be used (Lappas et al., 2014).

Starting from the Gaussen concept, Rivas-Martinez (1981) used the ratio between the sum of precipitation $\left(\mathrm{P}_{\mathrm{i}}\right.$ in $\left.\mathrm{mm}\right)$ and the sum of corresponding positive monthly temperatures $\left(\mathrm{T}_{\mathrm{i}}\right.$ in $\left.{ }^{\circ} \mathrm{C}\right)$ for a period of $n$ months. As is the case in the classification used in this paper, the limit of the dry period is also considered to be 2.0. Values above 3.6 indicate a humid climate, between 2.0 and 3.6 a dry climate, between 1.0 and 2.0 a semi-arid climate, while values below 1 indicate an arid climate (Rego and Rocha, 2014). The index is calculated according to the following formula:

$$
I_{n}=\frac{\sum_{n} P_{i}}{\sum_{n} T_{i}}
$$

The Emberger index (IE) (Emberger, 1930) is based on the mean annual precipitation and mean temperature of both the coldest and warmest months and is determined according to the formula:

$$
I E=\frac{100 x P}{M^{2}-m^{2}}
$$

where, $P$ is the annual average rainfall (mm), $M$ is the average temperature of the hottest month $\left({ }^{\circ} \mathrm{C}\right)$, and $m$ is the average temperature of the coldest month $\left({ }^{\circ} \mathrm{C}\right)$. According to IE, the climate type is humid if IE $>90$, subhumid if IE is $50-90$, semiarid if IE is $30-$ 50 , and arid if IE is $<30$. This index has been applied in numerous studies related to vegetation (Gavilán, 2005) for Spain, and (Savo et al., 2012) for Central ma se smatra suhom, između 10 i 20 polusuhom, a iznad 20 humidnom (Andrade i Corte-Real, 2016). Pinnin kombinirani indeks uglavnom se primjenjivao u sredozemnom području - Portugalu (Andrade i Corte-Real, 2016), sjevernoj Grčkoj (Baltas, 2007), Turskoj (Deniz i dr., 2011). Croitoru i dr. (2013) primijenili su ga u Rumunjskoj (izvankarpatska područja), a Cheval i dr. (2016) na razini kontinenta.

Gaussenova korelacija padalina i temperature grafički je način procjene klimatskih obilježja. Budući da je Gaussen smatrao kako je sušan mjesec određen odnosom $\mathrm{P} / \mathrm{T}<2$, na ordinatama $20 \mathrm{~mm}$ padalina treba odgovarati $10{ }^{\circ} \mathrm{C}$ (Lappas i dr., 2014).

Koristeći se Gaussenovim konceptom, Rivas-Martinez (1981) upotrebljava omjer zbroja količine padalina $\left(\mathrm{P}_{\mathrm{i}} \mathrm{u} \mathrm{mm}\right)$ i zbroja odgovarajućih pozitivnih mjesečnih temperatura $\left(\mathrm{T}_{\mathrm{i}} \mathrm{u}{ }^{\circ} \mathrm{C}\right)$ za razdoblje od $n$ mjeseci. I za ovu je klasifikaciju granična vrijednost za sušno razdoblje 2,0. Vrijednosti iznad 3,6 označavaju humidnu klimu, između 2,0 i 3,6 suhu klimu, između 1,0 i 2,0 semiaridnu klimu, a vrijednosti manje od 1 aridnu klimu (Rego i Rocha, 2014). Indeks se izračunava prema formuli:

$$
I_{n}=\frac{\sum_{n} P_{i}}{\sum_{n} T_{i}}
$$

Embergerov indeks (IE) (Emberger, 1930) temelji se na srednjim godišnjim količinama padalina i srednjoj temperaturi najhladnijega i najtoplijega mjeseca, a određuje se formulom:

$$
I E=\frac{100 x P}{M^{2}-m^{2}}
$$

gdje je $P$ godišnji srednjak padalina (mm), $M$ srednja temperatura najtoplijega mjeseca $\left({ }^{\circ} \mathrm{C}\right)$, a $m$ srednja temperatura najhladnijega mjeseca $\left({ }^{\circ} \mathrm{C}\right)$. Prema Embergerovu indeksu klima je humidna ako je IE > 90, subhumidna ako je IE između 50 i 90, semiaridna ako je IE od 30 do $50 \mathrm{i}$ aridna ako je IE < 30. Riječ je o indeksu primijenjenom u brojnim studijama povezanima s vegetacijom (Gavilán, 2005) za Španjolsku, te (Savo i dr., 2012) za 
Italy, and Emberger himself applied it in classifying phytoclimatic belts (Emberger, 1933; 1954).

Selyaninov's hydrothermal coefficient (HTC), developed by Selyaninov (1958), is calculated according to the formula:

$$
H T C=\frac{P}{\sum_{T>10} \frac{T}{10}}
$$

where $P$ is the sum of precipitation amounts (mm) and $T$ is the sum of temperature $\left({ }^{\circ} \mathrm{C}\right)$ for the months with mean temperatures $>10^{\circ} \mathrm{C}$, which mainly correspond to the vegetation period, namely April-October. This index can be also calculated at the monthly level, for the same period. HTC has been widely applied in different studies related to the determination of moist and dry periods ( $\mathrm{Ri}-$ azanova et al.,2016), the favourability of the climate for agriculture or natural vegetation development (Kwiatkowski, 2015; Leblois and Quirion, 2013), or economic studies (Melkonyan and Asadoorian, 2014). The classification of the values is rendered in Tab. 4. središnju Italiju, a sâm ju je Emberger upotrijebio za klasifikaciju fitoklimatskih pojaseva (Emberger, 1933; 1954).

Seljaninovljev hidrotermalni koeficijent (HTC) razvio je Selyaninov (1958), a izračunava se formulom:

$$
H T C=\frac{P}{\sum_{T>10} \frac{T}{10}}
$$

gdje je $P$ zbroj količine padalina $(\mathrm{mm})$, a $T$ zbroj temperatura $\left({ }^{\circ} \mathrm{C}\right)$ za mjesece sa srednjim temperaturama $>10{ }^{\circ} \mathrm{C}$, što uglavnom odgovara vegetacijskom razdoblju, odnosno razdoblju od travnja do listopada. Taj se indeks za neko razdoblje može izračunati i na mjesečnoj razini. HTC se često upotrebljavao u različitim istraživanjima povezanima s određivanjem vlažnih i sušnih razdoblja (Riazanova i dr., 2016), prikladnosti klime za poljoprivredu ili razvoj prirodne vegetacije (Kwiatkowski, 2015; Leblois i Quirion, 2013) te ekonomske studije (Melkonyan i Asadoorian, 2014). Granične vrijednosti klasifikacije prema HTC-u navedene su u Tab. 4.

Tab. 4 Climate classification according to HTC

Tab. 4. Klasifikacija klima prema HTC-U

\begin{tabular}{|c|l|}
\hline HTC & $\begin{array}{l}\text { Climate classification } \\
\text { / Klimatska klasifikacija }\end{array}$ \\
\hline 0.3 & Very dry or arid / Vrlo suha ili aridna \\
\hline $0.31-0.60$ & Dry / Suha \\
\hline $0.61-0.80$ & Moderately dry / Umjereno suha \\
\hline $0.81-1.00$ & Slightly dry / Neznatno suha \\
\hline $1.01-1.20$ & Slightly humid / Neznatno humidna \\
\hline $1.21-1.40$ & Moderately humid / Umjereno humidna \\
\hline $1.41-1.60$ & Humid / Humidna \\
\hline$>1.61$ & Very humid / Vrlo humidna \\
\hline
\end{tabular}

Source: adapted after Selyaninov, 1930

Izvor: prilagođeno prema Selyaninov, 1930

A. Ş Vlăduţ N. Nikolova M. Licurici

Aridity assessment within southern Romania and northern Bulgaria

Procjena aridnosti za južnu Rumunjsku i sjevernu Bugarsku 
HRVATSKI

GEOGRAFSKI

GLASNIK

$79 / 2,5-26(2017$.

\section{Results and discussion}

\section{De Martonne Aridity Index $\left(I_{a}\right)$}

In spite of the fact that this index is one of the oldest indices used for the determination of aridity or humidity conditions, as well as correlations with vegetation, it is still being used in numerous studies. Within the present study area, most of the annual values of $\mathrm{I}_{\mathrm{a}}$ indicated a semi-humid climate (Fig. 2). Along the Danube Valley, the climate was found to be semi-humid or humid in the western and central sectors, while in the east, at Galaţi and Tulcea, it was classified as Mediterranean. On the Black Sea shore, $\mathrm{I}_{\mathrm{a}}$ emphasised a semi-arid climate in Romania and a Mediterranean one in Bulgaria, due to higher precipitation amounts registered in Bulgaria compared to Romania. At higher altitudes, in the northern-western and central parts of the Romanian Plain, and within the pre-Balkan hills, the climate was generally

\section{Rezultati i rasprava}

\section{De Martonneov indeks aridnosti $\left(I_{a}\right)$.}

Unatoč tomu što je riječ o jednom od najstarijih indeksa za određivanje aridnosti ili humidnosti te veze s vegetacijom, još se uvijek rabi u brojnim istraživanjima. Unutar istraživanoga područja većina godišnjih vrijednosti za $\mathrm{I}_{\text {a }}$ upućuje na semihumidnu klimu (sl. 2). U dolini Dunava klima je semihumidna ili humidna u njezinu zapadnom i središnjem dijelu, dok se na istoku, u Galaţiju i Tulcei, pojavljuje sredozemna klima. Na obalama Crnoga mora prema I u Rumunjskoj je semiaridna klima, a u Bugarskoj zbog veće količine padalina u odnosu na Rumunjsku sredozemna klima. $\mathrm{Na}$ višim nadmorskim visinama u sjeverozapadnom i središnjem dijelu Rumunjske ravnice i u predbalkanskim brdima klima je, općenito, humidna, dok je u

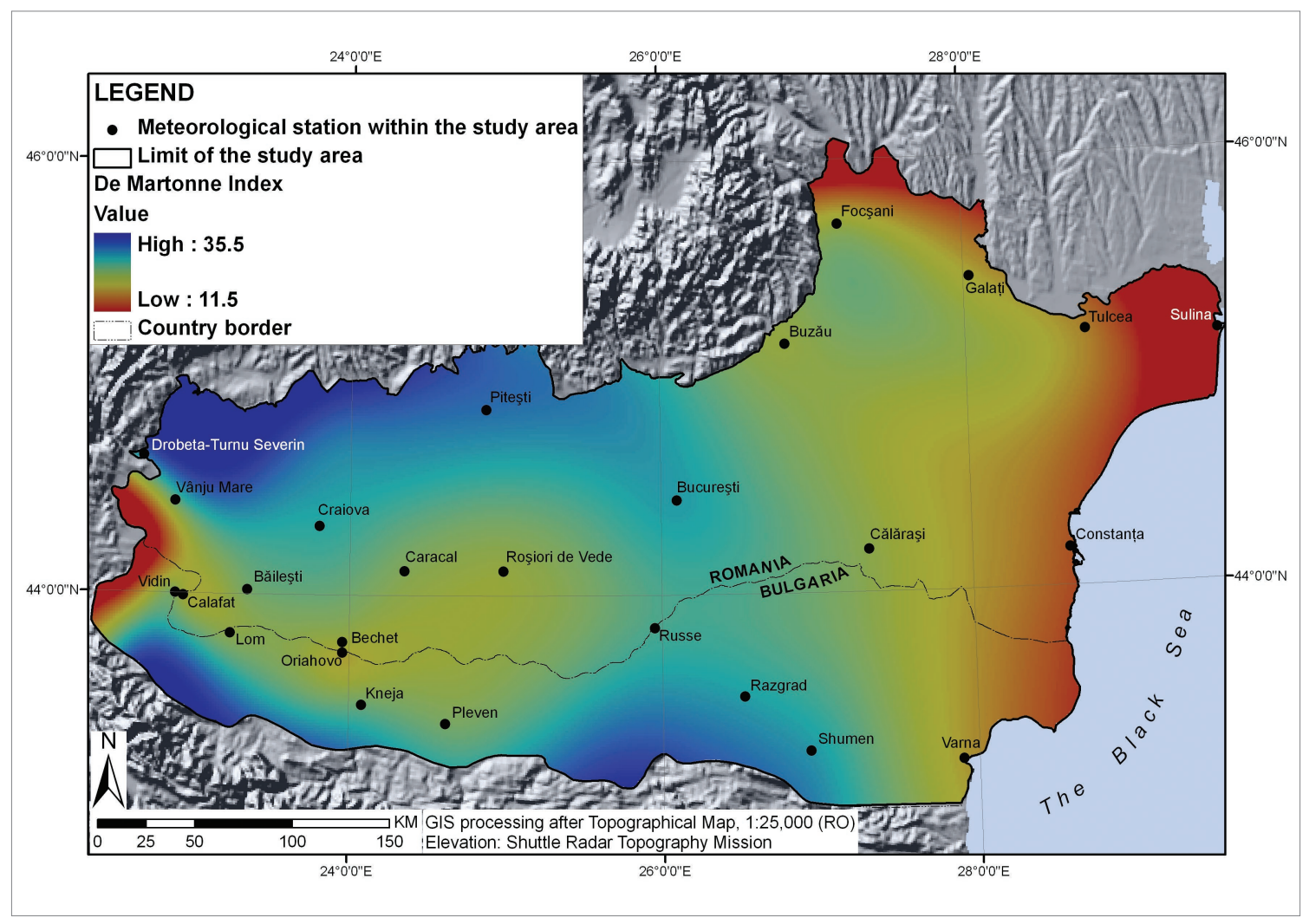

Fig. 2 De Martonne Aridity Index $\left(I_{a}\right)$ within the study area

SI. 2. De Martonneov indeks aridnosti (I) U istraživanom području 
humid, but the immediate surroundings, Belogradchik and Vratsa, were very humid (Fig. 2).

At the monthly level, there were noticeable territorial and temporal differences. Thus, humid and very humid conditions characterised the cold season, mainly January and December, while in summer, dry conditions were clearly predominant. In the extreme west, at D. T. Severin, $\mathrm{I}_{\mathrm{m}}$ indicated an extremely humid climate for December, the only case with such classification, while January was semiarid in the extreme east, at Sulina. The number of moderately dry and semiarid months increased starting with March, within the entire region, and the only areas with slightly humid or moderately humid climate were those located at higher altitudes, where temperature is lower and precipitation amounts higher. In the July-October interval, $86.7 \%$ of the analysed months were semiarid, $8.8 \%$ semi-dry, and $4.4 \%$ dry. Dry conditions were also registered in the extreme east, at Sulina (August and October) and at Tulcea (August). At Sulina, there were two other months characterised as arid, April and May, and this is the only station where all months of the year were classified as semiarid and arid.

\section{Pinna Combinative Index $\left(I_{p}\right)$}

This is also an index based on temperature and precipitation values. Taking into account that $\mathrm{I}_{\mathrm{p}}$ indicates a humid climate for values $>20$, a detailed territorial pattern could not be established. Within almost the entire study area, at annual level, $\mathrm{I}_{\mathrm{p}}$ values indicated a humid climate, as there were no great differences between mean temperature and precipitation values and the values registered in the driest months. However, there were great differences between the sectors of the analysed region, at Constanţa, in the east, $I_{p}$ was 23.41, while at Băileşti, in the west, it was 39.21. Most of the analysed meteorological stations presented values between 30 and 35. The shore of the Black Sea was determined to have a semi-dry climate (Varna), while the Danube Delta semi-dry (Tulcea) or even dry (Sulina). These results are consistent with the results obtained by Croitoru et al. (2013) or Cheval et al. (2016), who also predicted less dry conditions in the region for the 1991-2020 interval, but the extension of moderately dry conditions within most of the analysed region for the 2012-2050 interval. neposrednoj blizini, u Belogradčiku i Vraci, vrlo humidna (s1. 2).

$\mathrm{Na}$ mjesečnoj su razini prostorne i vremenske razlike puno izraženije. U hladnom dijelu godine, većinom u siječnju i prosincu, javljaju se humidni i vrlo humidni uvjeti, dok suhi uvjeti prevladavaju ljeti. Na krajnjem je zapadu, u D. T. Severinu, prema $I_{m}$ tijekom prosinca iznimno humidna klima, što je prema toj klasifikaciji jedini slučaj, dok je na krajnjem istoku, u Sulini, klima semiaridna. Broj postaja s umjereno suhim mjesecima u cijeloj regiji povećava se počevši s ožujkom, a jedina područja s neznatno humidnom ili umjereno humidnom klimom su ona na višim nadmorskim visinama, gdje su temperature niže, a količina padalina veća. U razdoblju od srpnja do listopada $86,7 \%$ analiziranih mjeseci je semiaridno, $8,8 \%$ polusuho, a $4,4 \%$ suho. Sušni uvjeti također se javljaju na krajnjem istoku, u Sulini (kolovoz i listopad) i u Tulcei (kolovoz). U Sulini su još dva mjeseca aridna - travanj i svibanj te je to jedina postaja u kojoj su svi mjeseci u godini semiaridni $\mathrm{i}$ aridni.

\section{Pinnin kombinirani indeks $\left(I_{p}\right)$}

Također se temelji na vrijednostima temperature i količine padalina. Kako I upućuje na humidnu klimu za vrijednosti > 20, ne može se provesti detaljnija prostorna analiza. Unutar gotovo cijeloga promatranog područja na godišnjoj razini vrijednosti I upućuju na humidnu klimu jer nema velikih razlika između srednjih temperatura i količine padalina te vrijednosti određenih za najsušnije mjesece. Ipak, postoje velike razlike među pojedinim dijelovima istraživane regije - u Constanţi, na istoku, I iznosi 23,41, a u Băileştiju, na zapadu, 39,21. Većina analiziranih meteoroloških postaja ima vrijednosti $I_{p}$ između 30 i 35. Na obali Crnoga mora klima je polusuha (Varna), a u delti Dunava je polusuha (Tulcea) ili čak suha (Sulina). Ti su rezultati u skladu s onima koje su dobili Croitoru i dr. (2013) te Cheval i dr. (2016), koji je također predvidio manje sušne uvjete u regiji za razdoblje 1991. - 2020., ali i prognozirao umjereno sušne uvjete unutar najvećega dijela promatrane regije za razdoblje 2012. -2050 .
A. Ş Vlăduţ

N. Nikolova

M. Licurici

Aridity assessment within southern Romania and northern Bulgaria

Procjena aridnosti za južnu Rumunjsku i sjevernu Bugarsku 


\section{Correlation between temperature and precipitation (Gaussen correlation)}

The months characterised by drought were those when the precipitation amounts were half of the mean temperature values. Typically, in the respective periods, irrigation is necessary in order to have good production, especially during the vegetation growing season. In the analysed region, summer months were particularly susceptible to the drought phenomena, mainly July and August, when temperature increase was accompanied by a reduction in the amount of precipitation. However, drought months or periods also appeared along the Danube Valley and in the extreme east, near the Black Sea coast (Fig. 3).

Thus, starting from the west, at D. T. Severin, the only dry month was August. At Calafat, August was also dry, but there was a longer drought period as July and September were very close to the drought threshold. The same situation was also noticed at Bechet, Oriahovo, and Lom. Along the Danube to the east, the drought period reduced to less than one month, in July (Galați). On the Black Sea shore, there was a longer drought period, generally starting in June and ending in September (Constanța, Varna). The only station with a longer drought period was Sulina, in the extreme eastern part of the study area, where drought began starting in mid-March and lasted until the end of October.

The method proposed by Rivas-Martinez (1981) $\left(I_{n}\right)$ was applied to the months with positive temperatures, which generally means a total of 11 months for most of the stations, with few exceptions, such as the coastal area with positive values, or the northern part of the study area, where there are two or three months with negative temperatures, depending on the location. $I_{n}$ highlighted almost the same situation as Gaussen correlation, namely the lower areas located within the Danube Alluvial Plain and along the shore of the Black Sea had dry conditions, while at higher altitudes the climate was humid (Fig. 4). At Sulina, the climate was semi-arid, a result consistent with the results obtained when applying all the other aridity indices.
Korelaciia temperature i količine padalina (Gaussenova korelacija).

Sušni mjeseci su oni s vrijednošću količine padalina manjom od dvostrukih vrijednosti srednje temperature. Obično je u tim razdobljima potrebno navodnjavanje kako bi se postigli dobri prinosi, pogotovo ako je suša u vrijeme rasta vegetacije. $U$ istraženom području ljetni su mjeseci osobito podložni pojavi suše, posebice tijekom srpnja i kolovoza, kad je porast temperature popraćen smanjenjem količine padalina. Međutim, sušni mjeseci ili razdoblja mogu se javiti i u dolini Dunava te na krajnjem istoku, blizu obale Crnoga mora (sl. 3).

Tako je, počevši od zapada, od D. T. Severina, jedini sušni mjesec kolovoz. U Calafatu je kolovoz također suh, ali je sušno razdoblje duže jer su i srpanj i rujan vrlo blizu graničnih vrijednosti za sušu. Ista je pojava zabilježena u Bechetu, Oriahovu i Lomu. Prema istoku,dolinom Dunava, sušno razdoblje traje kraće od jednoga mjeseca, a javlja se u srpnju (Galați). Na obali Crnoga mora razdoblje suše je dulje i najčešće počinje u lipnju te traje do rujna (Constanța, Varna). Jedina postaja s duljim sušnim razdobljem je Sulina, na krajnjem istočnom dijelu promatranoga područja, gdje suša počinje sredinom ožujka i traje do kraja listopada.

Metoda koju je predložio Rivas-Martinez (1981) (I I primijenjena je na mjesece s pozitivnom temperaturom, tj. na ukupno 11 mjeseci u većini postaja, s malo iznimaka, kao što je obalno područje u kojem su sve vrijednosti pozitivne, odnosno sjeverni dio promatranoga područja u kojem, ovisno o lokaciji, budu dva ili tri mjeseca s negativnim temperaturama. $\mathrm{I}_{\mathrm{n}}$ daje gotovo jednake rezultate kao i Gaussenova korelacija, odnosno sušni uvjeti vladaju u nizinskim područjima uz naplavnu ravnicu Dunava i uz obalu Crnoga mora, a humidna je klima na većim nadmorskim visinama (s1. 4). U Sulini je klima semiaridna pa je rezultat podudaran $\mathrm{s}$ rezultatima dobivenim primjenom ostalih pokazatelja aridnosti. 

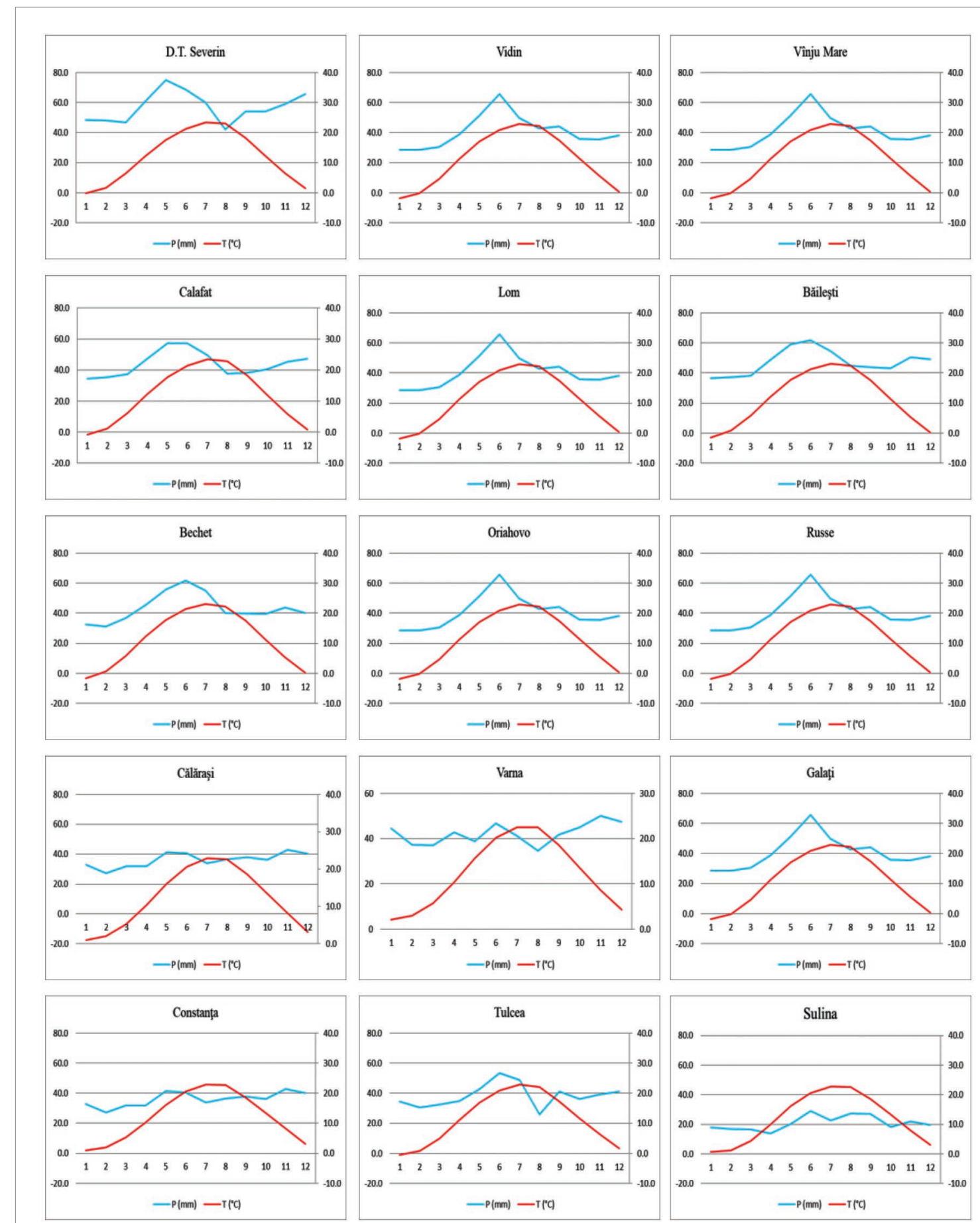

Fig. 3 Correlation between temperature and precipitation amounts (Gaussen correlation) within the Danube Alluavial Plain and on the shore of the Black Sea

SI. 3. Korelacija temperature i količine padalina (Gaussenova korelacija) na naplavnoj ravnici Dunava i na obali Crnoga mora 
HRVATSKI

GEOGRAFSKI

GLASNIK

79/2,5-26 (2017.)

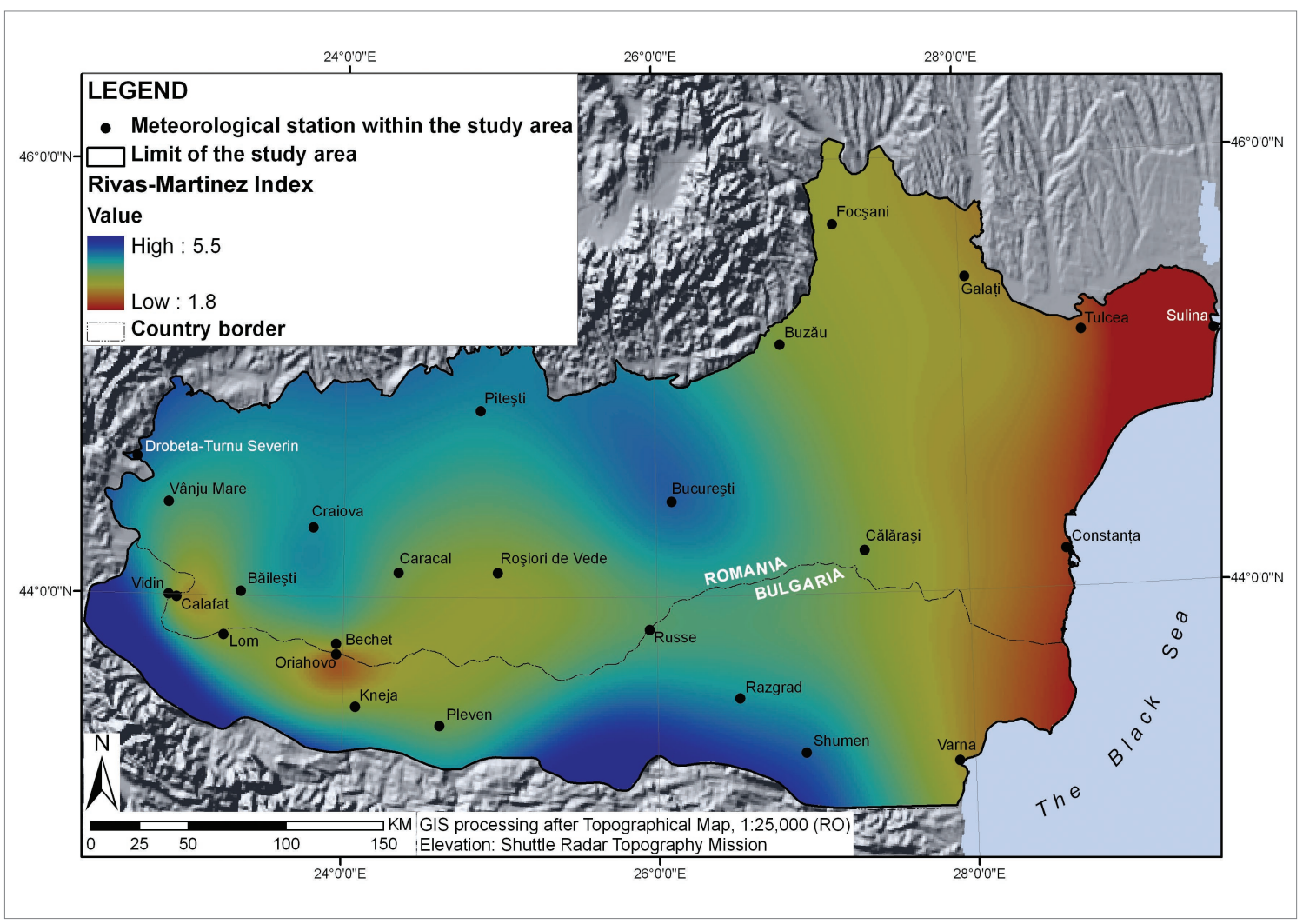

Fig. 4 Rivas-Martinez Index $\left(I_{n}\right)$ within the study area

SI. 4. Rivas-Martinezov indeks $\left(I_{n}\right) \cup$ istraživanom području

\section{Emberger index}

(IE) as well as $I_{p}$ showed a humid climate within the entire study area, except on the Romanian shore of the Black Sea (Constanţa) and the Danube Delta, where the results indicated a sub-humid climate at Tulcea and a semi-arid climate at Sulina. However, as humid climate is characterised by IE values $>90$, there were territorial differences, overlapping results obtained when applying the other indices.

Thus, the lowest values, between 91 and 96 , which are very close to the sub-humid threshold, were registered along the Danube, particularly in the extreme western and eastern areas (Calafat, Bechet, Oriahovo and Galaţi). At higher altitudes, the values were around 110-120, but IE even reached 150 at Pitești, with the highest altitude within the study area, and between 150 and 170 in Bulgaria, in the immediate proximity of the lowland area at the foot of the mountains.

\section{Embergerov indeks}

(IE) kao i I za cijelo istraživano područje daje humidnu klimu, osim na rumunjskoj obali Crnoga mora (Constanţa) i u delti Dunava, gdje se prema dobivenim razultatima subhumidna klima javlja u Tulcei te semiaridna klima u Sulini. Međutim, kako humidnu klimu obilježavaju vrijednosti IE > 90, postoje prostorna nepodudaranja s rezultatima dobivenim primjenom drugih pokazatelja.

Tako su najniže vrijednosti, između 91 i 96, vrlo blizu granične vrijednosti za subhumidnu klimu, zabilježene duž Dunava, osobito na krajnjem zapadnom i istočnom dijelu (Calafat, Bechet, Oriahovo i Galaţi). Na većim nadmorskim visinama vrijednosti su oko 110 - 120, a IE je dosegao vrijednost od čak 150 u Piteștiju, mjestu s najvećom nadmorskom visinom u istraživanom području, odnosno od 150 do 170 u Bugarskoj u neposrednoj blizini nizinskoga područja uz podnožje planina. 


\section{Selyaninov's hydrothermal coefficient (HTC)}

This coefficient has mainly been applied in Russia and ex-soviet states, and in countries from the Central and Eastern Europe such as Kazakhstan (Salnikov et al., 2016), Bulgaria (Kazadjiev et al., 2012), Poland (Zmudzka, 2004), Moldova, and Romania (Armaş et al., 2016). HTC values, calculated on the basis of average values for the April-October period, highlighted important territorial differences within the study area (Fig. 5). Thus, the climate was moderately humid only in the central-northern extremity of the Romanian Plain, at higher altitudes (above $250 \mathrm{~m}$ ), or in the immediate proximity of the study area, at the foot of the mountains in Bulgaria. A slightly humid climate also characterised the northern part of the Romanian Plain, at lower altitudes, and the southern sectors of the plain territory in Bulgaria. All the stations located along the Danube or in the immediate proximity displayed a slightly dry climate, with the lowest HTC values registered

\section{Seljaninovljev hidrotermalni koeficijent (HTC)}

Rabio se većinom u Rusiji i bivšim sovjetskim državama te u zemljama srednje i istočne Europe poput Kazahstana (Salnikov i dr., 2016), Bugarske (Kazadjiev i dr., 2012), Poljske (Zmudzka, 2004), Moldavije i Rumunjske (Armaş i dr., 2016). Vrijednosti HTC-a, izračunane na temelju srednjih vrijednosti u razdoblju od travnja do listopada u promatranom području pokazuju značajna prostorna odstupanja (sl. 5). Tako je klima umjereno humidna samo u krajnjem sjevernom dijelu središnje rumunjske ravnice, na višim nadmorskim visinama (iznad $250 \mathrm{~m}$ ) i u južnim dijelovima bugarske ravnice, uz podnožje planina. Neznatno humidna klima javlja se na sjevernom dijelu rumunjske ravnice, na nižim nadmorskim visinama i u južnim dijelovima ravnica u Bugarskoj. Sve postaje duž Dunava ili u neposrednoj blizini imaju neznatno suhu klimu s najnižim zabilježenim vrijednostima u zapadnim i

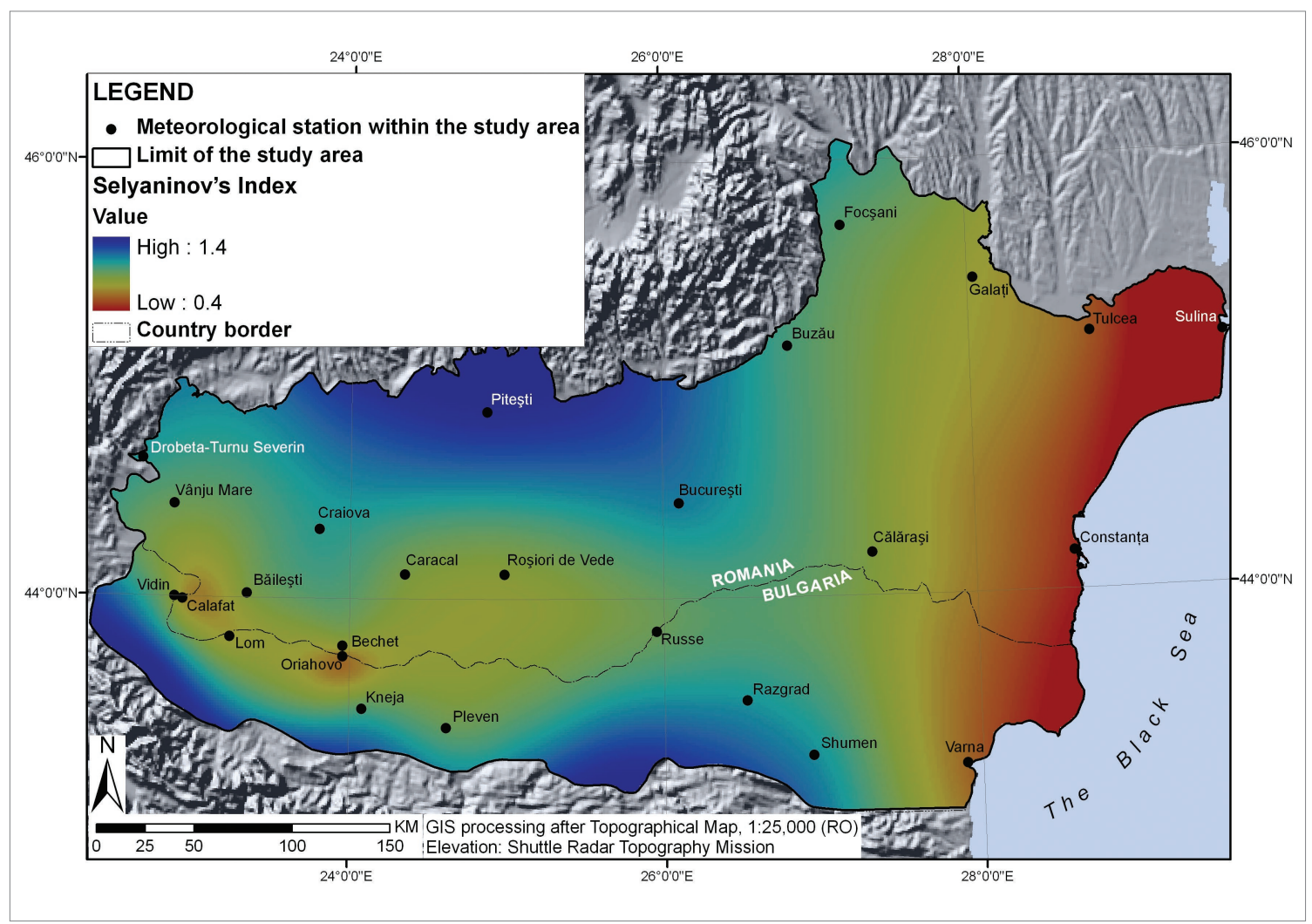

Fig. 5 Selyaninov's hydrothermal coefficient (HTC) within the study area

SI. 5. Seljaninovljev hidrotermalni koeficijent (HTC) U istraživanom području

A. Ş Vlăduţ N. Nikolova M. Licurici

Aridity assessment within southern Romania and northern Bulgaria

Procjena aridnosti za južnu Rumunjsku i sjevernu Bugarsku 
HRVATSKI

GEOGRAFSKI

GLASNIK

79/2,5-26 (2017.) in the western and eastern sectors (Calafat -0.84 , Bechet -0.88 , Lom -0.86 , respectively Galați 0.87). Moderately dry conditions were registered at Oriahovo, within the Danube Alluvial Plain, at Tulcea (in the extreme western part of the Danube Delta), and on the shore of the Black Sea. Sulina was the only station with a dry climate (HTC - 0.42). Thus, the HTC results generally indicated the same situation as the other aridity indices (Fig. 5).

Selyaninov's hydrothermal coefficient (HTC), calculated at the monthly level showed aridity to be widely spread between June and September. The driest month was August, which was classified as dry at most of the stations from the western part of study area and in the Black Sea region (Fig. 6). According to the HTC, in most of the stations from the central part of the researched region, moderately dry conditions were observed in August. A decrease of the number of dry months and increase of slightly dry months was observed in July and September. In June the aridity was observed mainly along the Danube, in the western part of the study area, and in the Black Sea region. The aridity was well expressed in the eastern part of the region, east of the geographical longitude $27^{\circ} 57^{\prime}$ where, during five months (May-September), HTC showed dry istočnim dijelovima istraživanoga prostora (Calafat - 0,84, Bechet -0,88, Lom - 0,86, odnosno Galați - 0,87). Umjereno suhi uvjeti zabilježeni su u Oriahovu, u naplavnoj ravnici Dunava, u Tulcei (na krajnjem zapadu delte Dunava) i na obali Crnoga mora. Sulina je jedina postaja sa suhom klimom (HTC - 0,42). Rezultati dobiveni korištenjem HTC-a odgovaraju rezultatima dobivenim ostalim pokazateljima aridnosti (sl. 5).

Seljaninovljevi hidrotermalni koeficijenti (HTC) izračunani na mjesečnoj razini pokazuju da se aridnost javlja između lipnja i rujna. Najsuši je mjesec kolovoz, koji je sušan u većini postaja na zapadnom dijelu istraživanoga područja i na obali Crnoga mora (sl. 6). Prema HTC-u, u većini postaja u središnjem dijelu istraživanoga područja u kolovozu su zabilježeni umjereno sušni uvjeti. Smanjenje broja suhih mjeseci i povećanje broja neznatno suhih mjeseci javlja se u srpnju i rujnu. U lipnju je aridnost opažena ponajprije duž Dunava u zapadnom dijelu istraživanoga područja i na obali Crnoga mora. Aridnost je dobro izražena $u$ istočnom dijelu područja, istočno od geografske dužine $27^{\circ} 57^{\prime}$, gdje tijekom pet mjeseci (svibanj - rujan) prema HTC-u postoje sušni uvjeti. Četiri suha mjeseca

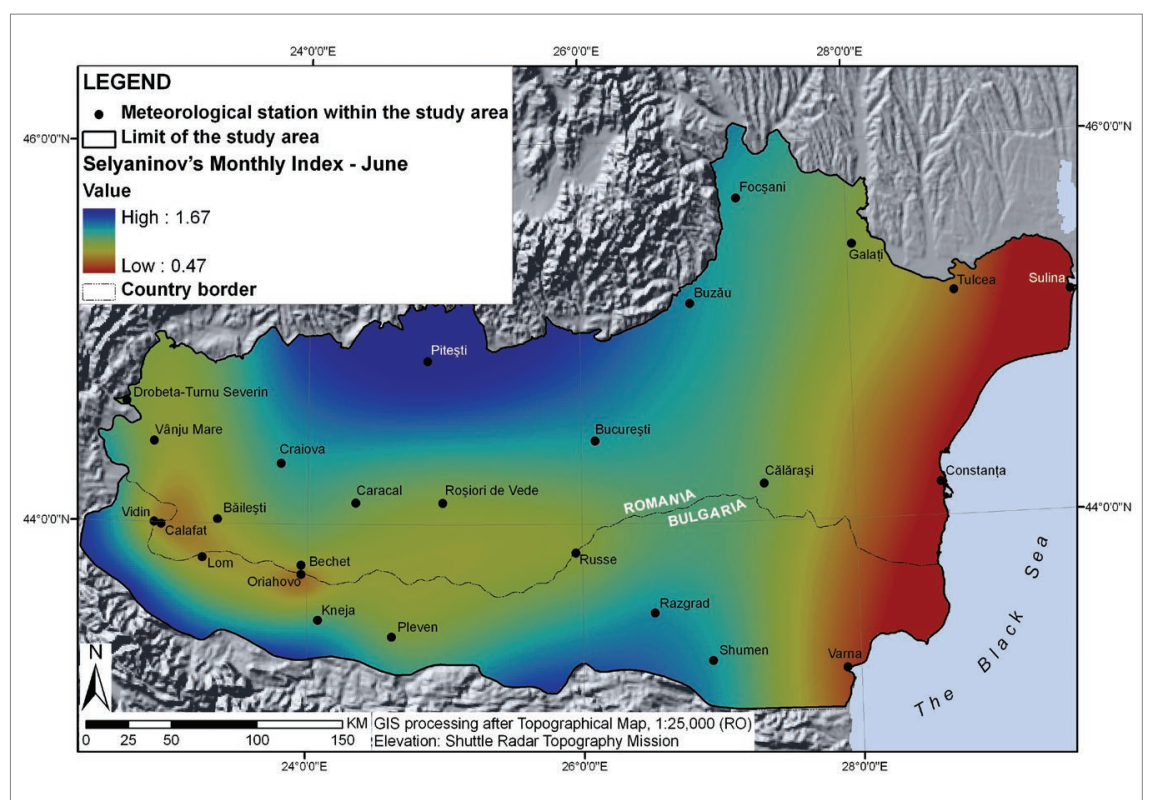

Fig. 6a Selyaninov's hydrothermal coefficient (HTC) within the study area during the summer months - June

SI. 6a Seljaninovljev hidrotermalni koeficijent (HTC) U istraživanom području tijekom ljetnih mjeseci - lipanj 
Fig. 6b Selyaninov's hydrothermal coefficient (HTC) within the study area during the summer months - July

SI. 6b Seljaninovljev hidrotermalni koeficijent (HTC) u istraživanom području tijekom ljetnih mjeseci - srpanj

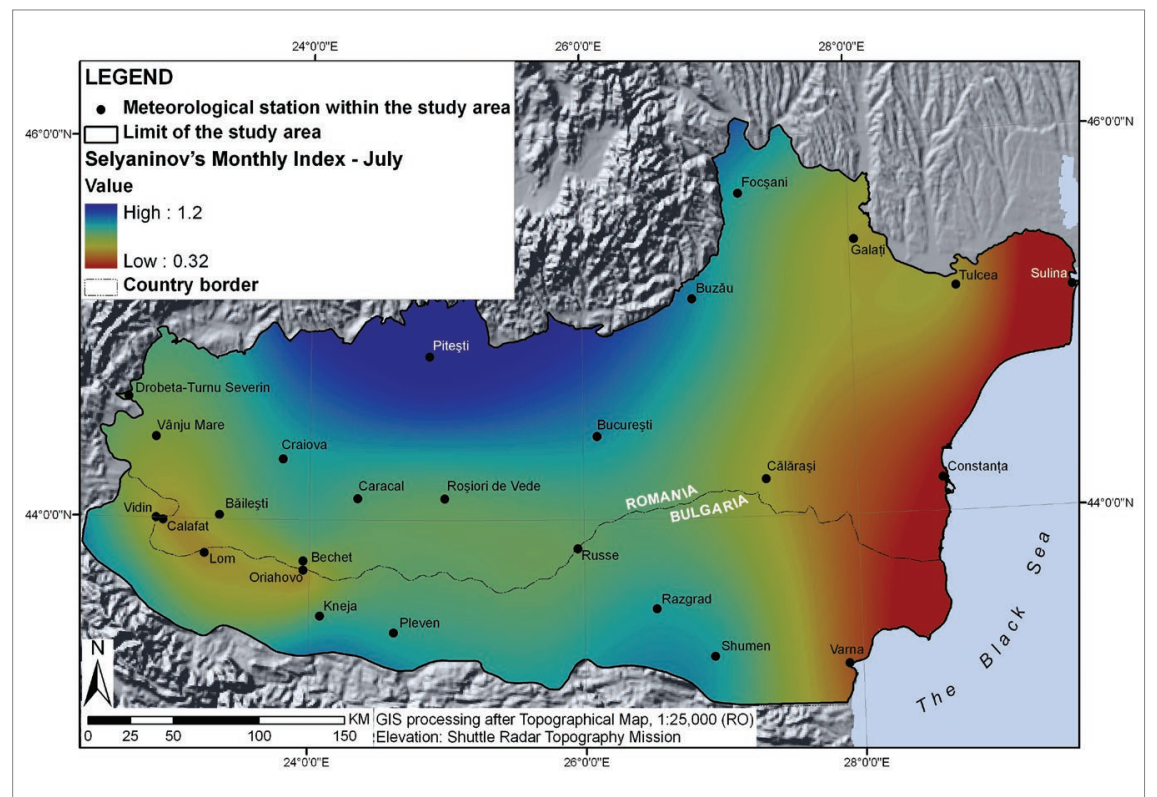

A. Ş Vlăduţ

N. Nikolova

M. Licurici

Aridity assessment within southern Romania and northern Bulgaria

Procjena aridnosti za južnu Rumunjsku i sjevernu Bugarsku

Fig. 6c Selyaninov's hydrothermal coefficient (HTC) within the study area during the summer months - August

SI. 6c Seljaninovljev hidrotermalni koeficijent (HTC) u istraživanom području tijekom ljetnih mjeseci - kolovoz

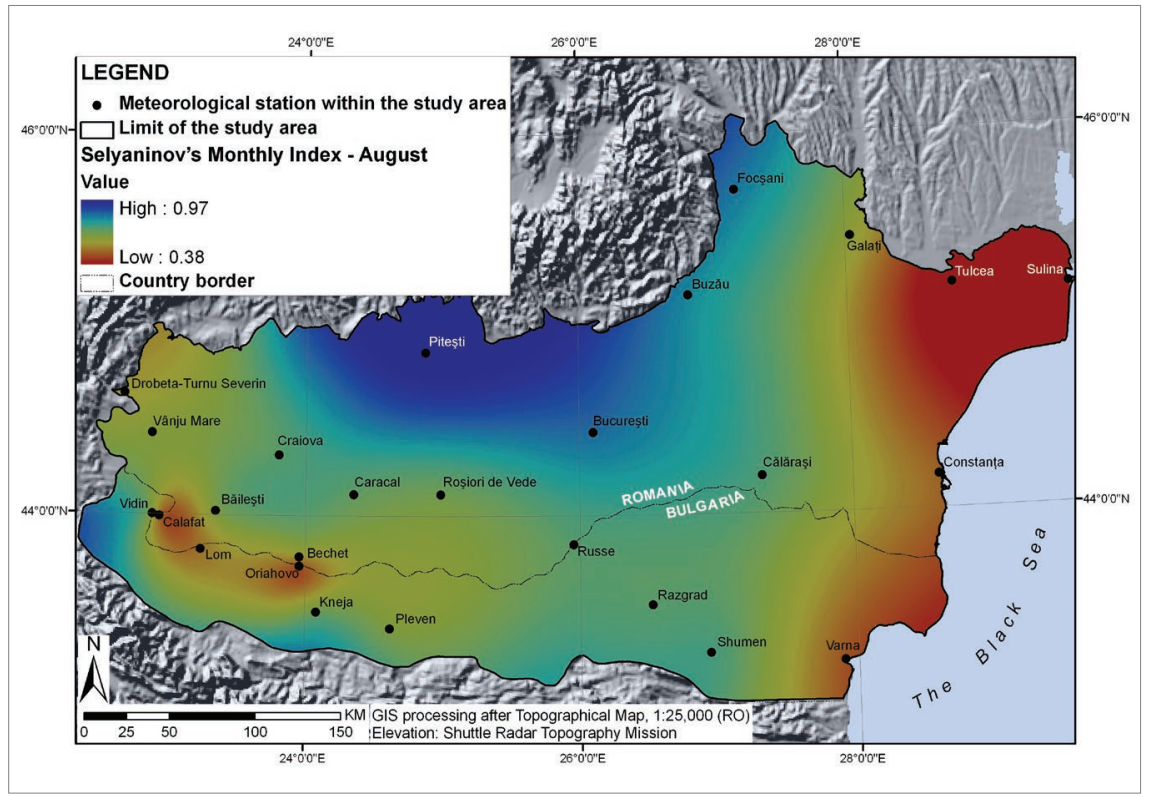

conditions. Four dry months (June-September) were identified in the western part of the study area; April, May and October were generally humid months. HTCs varied between slightly humid and humid. The only exception was the Black Sea region, where aridity conditions were predominant. Very humid conditions were established in April at the stations D. T. Severin and Pitești. (lipanj - rujan) javljaju se u zapadnom dijelu promatranoga područja. Travanj, svibanj i listopad su općenito humidni mjeseci. Vrijednosti HTC-a variraju između neznatno humidnih i humidnih uvjeta. Jedina je iznimka područje uz Crno more, gdje prevladavaju aridni uvjeti. Vrlo humidni uvjeti u travnju zabilježeni su u postajama D. T. Severin i Pitești. 
GEOGRAFSKI

GLASNIK

$79 / 2,5-26(2017$.

\section{Correlation of the analysed indices}

The relation between researched aridity indices was studied based on the Pearson correlation coefficient. If values of the coefficient are near +1.0 , then it is considered to have a perfect positive correlation, between +0.50 and +1.0 , a strong positive correlation, between 0.30 and 0.49 , a medium positive correlation and below +0.29 , a small positive correlation (Pearson's Correlation Coefficient - Statistics Solutions, 2017). We considered values above $0.95(\alpha=0.05)$, as statistically significant as they are closer to 1 and indicate a strong positive correlation (Fig. 7). Thus, the only index that showed non-significant statistical correlations with the other indices was $\mathrm{I}_{\mathrm{p}}$. The values of the Pearson correlation coefficient were 0.96 for $\mathrm{I}_{\mathrm{a}} / \mathrm{IE}, 0.98$ for $\mathrm{I}_{\mathrm{a}} / \mathrm{I}_{\mathrm{n}}, 0.97$ for $\mathrm{I}_{\mathrm{a}} / \mathrm{HTC}, 0.95$ for IE / $\mathrm{I}_{\mathrm{n}}, 0.97$ for IE /HTC, and 0.95 for $\mathrm{I}_{\mathrm{n}} / \mathrm{HTC}$. $\mathrm{I}_{\mathrm{p}}$, as mentioned, had strong positive correlation values between $0.69\left(\mathrm{I}_{\mathrm{p}} / \mathrm{IE}\right)$ and 0.74 ( $\left.\mathrm{I}_{\mathrm{p}} / \mathrm{HTC}\right)$, but they were not considered to be statistically significant.

Thus, the results from correlation analysis showed that the most appropriate indices for studying arid conditions were: De Martonne index $\left(\mathrm{I}_{\mathrm{a}}\right)$; Emberger (IE); Rivas-Martinez index $\left(\mathrm{I}_{\mathrm{n}}\right)$; and Selyaninov's index (HTC).

\section{Korelacija analiziranih pokazatelja}

Odnos između korištenih pokazatelja aridnosti analiziran je na temelju Pearsonova koeficijenta korelacije. Ako su njegove vrijednosti blizu $+1,0$, smatra se da je korelacija potpuno pozitivna, ako su vrijednosti između $+0,50$ i $+1,0$ korelacija je jako pozitivna, između $+0,30$ i $+0,49$ korelacija je srednje pozitivna, a ispod +0,29 malo je pozitivna (Pearson's Correlation Coefficient - Statistics Solutions, 2017). Statistički značajnima smatrane su vrijednosti iznad 0,95 $(\alpha=0,05)$ jer su blizu 1 i upućuju na jaku pozitivnu korelaciju (sl. 7). Tako je jedini indeks koji nije pokazivao statistički značajnu korelaciju s drugim indeksima bio I. Vrijednosti Pearsonova koeficijenta korelacije su 0,96 za I/IE, 0,98 za $\mathrm{I}_{\mathrm{a}} / \mathrm{I}_{\mathrm{n}}, 0,97 \mathrm{za} \mathrm{I} / \mathrm{HTC}, 0,95 \mathrm{za} \mathrm{IE} / \mathrm{I}_{\mathrm{n}}, 0,97 \mathrm{za} \mathrm{IE/}$ HTC i 0,95 za I/HTC. Pokazatelj I , kako je spomenuto, ima jaku pozitivnu korelaciju izmedu 0,69 (I $/ \mathrm{IE})$ i 0,74 ( $\left.\mathrm{I}_{\mathrm{p}} / \mathrm{HTC}\right)$, ali te vrijednosti nisu smatrane statistički značajnima.

Stoga su rezultati korelacijske analize pokazali da su najprikladniji indeksi za proučavanje aridnosti De Martonneov indeks $\left(\mathrm{I}_{\mathrm{a}}\right)$, Embergerov indeks (IE), Rivas-Martinezov indeks $\left(\mathrm{I}_{\mathrm{n}}\right)$ i Seljaninovljev indeks (HTC).

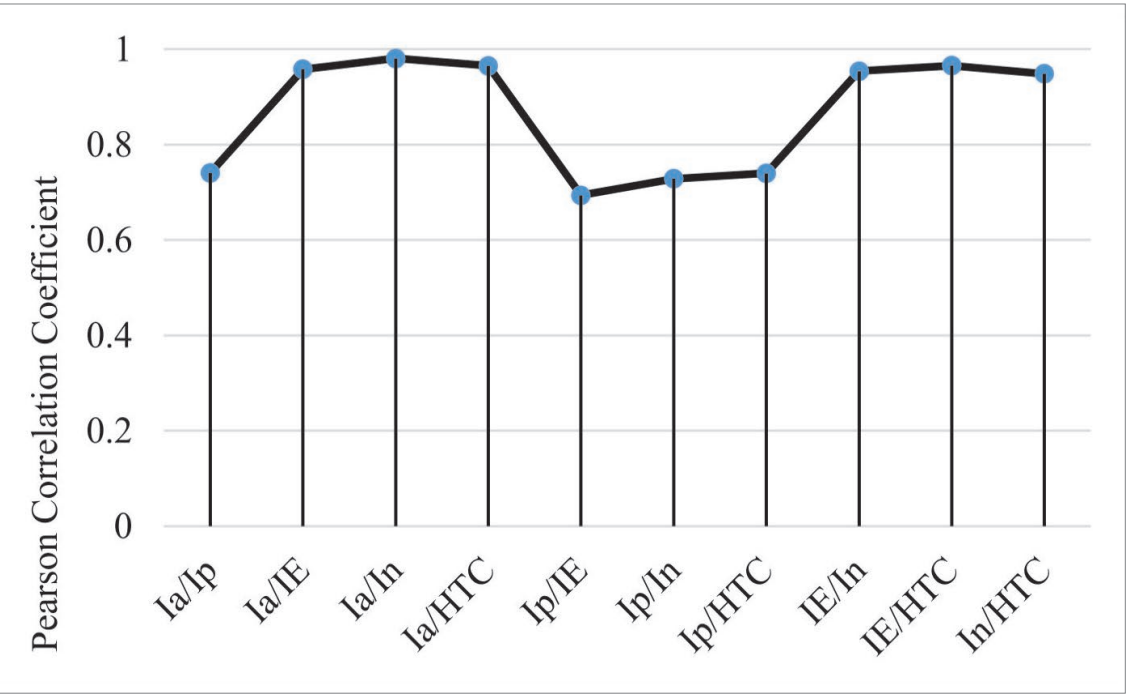

Fig. 7 Pearson correlation coefficient for the calculated indices

SI. 7. Pearsonov koeficijent korelacije za izračunane pokazatelje 


\section{Conclusion}

In light of recent climate change, the assessment of drought and aridity conditions has gained in importance. Consequently, numerous research methods have been applied in regions of varying size worldwide, as the issue of climate change potentially has great negative social and economic impacts. The analysed region, which consists of the southern part of Romania and the northern part of Bulgaria, is a vast lowland region, characterised by both temperature (increasing values) and precipitation (fluctuating amounts) variability; therefore, the assessment of aridity has become an important objective in the region. Several indices widely used in the assessment of aridity worldwide were applied: De Martonne Aridity Index; Gaussen correlation and Rivas-Martinez Index; Selyaninov's hydrothermal coefficient; Pinna Combinative Index; and Emberger index.

Thus, according to $I$, the annual values indicated a semi-humid climate within most of the lower areas of the plain, including the Danube Valley, humid climate in the western and northern sectors of the Romanian Plain and within the pre-Balkan hills, while in the east, at Galaţi and Tulcea, Mediterranean climate prevailed. On the Black Sea shore, the climate was semi-arid in Romania and Mediterranean in Bulgaria. $I_{p}$ indicated a humid climate within almost the entire study area, in spite of the differences between various sectors. The only areas with different values compared to the rest of the analysed region were the shore of the Black Sea: semi-dry climate (Varna) and the Danube Delta, semi-dry (Tulcea) or even dry (Sulina). $I_{n}$ showed almost the same pattern as the Gaussen correlation. Thus, drier conditions were registered within the lowers sectors of the plain and along the shore of the Black Sea, while the higher altitudes displayed a humid climate. Semi-arid climate was found only within the Danube Delta. IE emphasised the same distribution pattern as $I_{p}$, which means a humid climate within the entire study area, except the Romanian shore of the Black Sea (Constanţa) and the Danube Delta (sub-humid climate at Tulcea and semi-arid at Sulina). HTC displayed a statistically significant correlation with $\mathrm{I}_{2}$ (0.97), IE (0.97) and $\mathrm{I}_{\mathrm{n}}(0.95)$. Consequently, the climate was shown to be slightly humid or moderately humid in the Romanian Plain, at higher altitudes (above $250 \mathrm{~m}$ ) or at the

\section{Zaključak}

U svjetlu suvremenih promjena klime sve je veća važnost procjene pojave suša i aridnih uvjeta. Budući da te promjene imaju izrazito negativan društveni i ekonomski utjecaj, u različitim dijelovima svijeta koriste se brojne metode istraživanja. Istraživano područje, južni dio Rumunjske i sjeverni dio Bugarske, veliko je nizinsko područje s velikom temperaturnom (porast vrijednosti) i padalinskom (promjenjive količine) varijabilnošću te je stoga procjena aridnosti za to područje vrlo važna. U istraživanju je primijenjeno nekoliko najčešćih pokazatelja - De Martonneov indeks aridnosti, Gaussenova korelacija i Rivas-Martinezov indeks, Seljaninovljev hidrotermalni koeficijent, Pinnin kombinirani indeks i Embergerov indeks.

Prema pokazatelju $I_{a}$, godišnje vrijednosti upućuju na semihumidnu klimu u većem dijelu nižih područja ravnica, uključujući i dolinu Dunava, humidnu klimu u zapadnim i istočnim dijelovima rumunjske ravnice, uključujući i predbalkanska brda, dok na istoku, u Galaţiju i Tulcei, prevladava mediteranska klima. $\mathrm{Na}$ obalama Crnoga mora klima je semiaridna u Rumunjskoj, a sredozemna u Bugarskoj. Unatoč određenim odstupanjima $I_{p}$ upućuje na humidnu klimu na gotovo cijelom istraživanom području. Jedino područje koje se razlikuje u odnosu na ostatak istraživanoga područja jest obala Crnoga mora, gdje je klima polusuha (Varna) te delta Dunava, gdje je klima polusuha (Tulcea) ili čak suha (Sulina). Pokazatelj $I_{n}$ daje gotovo iste rezultate kao i Gaussenova korelacija. Sušni su uvjeti zabilježeni u nižim dijelovima ravnice i uz obale Crnoga mora, a na većim nadmorskim visinama klima je humidna. Semiaridna klima javlja se samo u delti Dunava. IE pokazuje istu prostornu raspodjelu kao i $I_{p}$, što znači da je klima humidna na cijelom istraživanom području osim na rumunjskoj obali Crnoga mora (Constanţa) i u delti Dunava (subhumidna klima u Tulcei i semiaridna u Sulini). HTC pokazuje statistički značajnu korelaciju s $I_{a}(0,97)$, IE $(0,97)$ i $I_{n}$ $(0,95)$. Prema tome, klima je neznatno humidna ili umjereno humidna na rumunjskoj ravnici,
A. Ş Vlăduţ N. Nikolova M. Licurici

Aridity assessment within southern Romania and northern Bulgaria

Procjena aridnosti za južnu Rumunjsku i sjevernu Bugarsku 
GEOGRAFSKI

GLASNIK

79/2, 5-26 (2017.)

Note

Napomena

Literatura

Literature foot of the mountains in Bulgaria. Drier conditions appeared along the Danube and on the shore of the Black Sea, while the extreme eastern part of the Danube Delta presented a dry climate once again.

The results indicated that, besides the coastal area and the Danube Delta, the most sensitive areas to aridity were the western and parts of the central sector of the Danube Valley, in both countries. When applied at the monthly level (for two indices: De Martonne aridity index and Selyaninov's hydrothermal coefficient), the most susceptible seasons were summer, mainly July and August, and autumn, mainly September and October, when semi-dry and dry conditions affected the entire analysed region, including higher altitude areas.

Furthermore, it must be taken into account that these indices have been applied in different regions of the world, not all of them are equally suitable to render aridity conditions at the global level. Thus, in the climatic conditions of southern Romania and northern Bulgaria, the results from the correlation analysis emphasised that the most appropriate indices are: De Martonne index ( $\mathrm{I}_{\mathrm{a}}$ ); Emberger (IE); Rivas-Martinez index $\left(\mathrm{I}_{\mathrm{n}}\right)$; and Selyaninov's index (HTC).

Professional Terms Editing:

Mladen Maradin, PhD, Assistant Professor

Translation: Ruđer Jeny na većim nadmorskim visinama (iznad $250 \mathrm{~m}$ ) i u podnožju bugarskih planina. Sušne uvjete nalazimo uz Dunav i na obali Crnoga mora, dok istočni dio delte Dunava ima suhu klimu.

Rezultati pokazuju da su u objema zemljama, osim obale i delte Dunava, područja zapadnoga i dijelom središnjega dijela nizine Dunava najosjetljivija na aridnost. $\mathrm{Na}$ mjesečnoj su razini (za dva pokazatelja - De Martonneov indeks aridnosti i Seljaninovljev hidrotermalni koeficijent) ljeto (uglavnom srpanj i kolovoz) i jesen (uglavnom rujan i listopad) razdoblja najosjetljivija na sušu, kada polusušni i sušni uvjeti utječu na cijelo promatrano područje, uključujući i područja na većim nadmorskim visinama.

Treba također uzeti u obzir da su navedeni pokazatelji korišteni u različitim dijelovima svijeta te nisu svi jednako prikladni za procjenu aridnosti na globalnoj razini. Za klimatske uvjete južne $\mathrm{Ru}-$ munjske i sjeverne Bugarske rezultati korelacijske analize pokazuju da su za procjenu aridnosti najprikladniji De Martonneov indeks ( $\left.\mathrm{I}_{\mathrm{a}}\right)$, Embergerov indeks (IE), Rivas-Martinezov indeks $\left(\mathrm{I}_{\mathrm{n}}\right)$ i Seljaninovljev indeks (HTC).

\author{
Stručna redaktura: \\ doc. dr. sc. Mladen Maradin \\ Prijevod: Ruđer Jeny
}

Andrade, C., Corte-Real, J., 2016: Aridity conditions in the Iberian Peninsula during the XX century, International Journal of Environmental Science 1, 52-58.

Armaş, A., Man, E. T, Constantinescu, L., Ienciu, A., Mazăre, V., Cuzic, O., Tentiuc, C., 2016: Climate Effects and the Extent of Dryness in Republic of Moldova, Analele Universităţii din Oradea, Fascicula Protecția Mediului 27, 189-196.

Baltas, E., 2007: Spatial distribution of climatic indices in northern Greece, $M e^{-}$ teorological Applications 14, 69-78, DOI: 10.1002/met.7.

Chendeş, V., Cheval, S., Dumitru, S., 2010: The Assessment of some Hydrological Drought Indices in the Bend Subcarpathians and Peripheral Zones, Research Journal of Agricultural Science 42 (3), 60-70.

Cheval, S., Dumitrescu, A., Birsan, M. V., 2016: Variability of the aridity in the South-Eastern Europe over 1961-2050, Catena 151, 74-86, DOI: 10.1016/j.catena.2016.11.029.

Coscarelli, R., Gaudio, R., Caloiero, T., 2004: Climatic trends: an investigation for a Calabrian basin (southern Italy), the basis of Civilization - water science?, Proceedings of the UNESCO/ IAHS/1WHA Symposium, Rome, December 2003. 1AI1S Publ 286, 255-266.

Croitoru, A. E., Piticar, A., Imbroane, A. M., Burada, D. C., 2013: Spatiotemporal distribution of aridity indices based on temperature and precipitation in the extra-Carpathian regions of Romania,
Theoretical and Applied Climatology 112 (3), 597-607, DOI: 10.1007/s00704012-0755-2.

De Martonne, E., 1926: Une nouvelle fonction climatologique: L'indice d'aridité, La Meteorologie, 449-458.

Deniz, A., Toros, H., Incecik, S., 2011: Spatial variations of climate indices in Turkey, International Journal of Climatology 31, 394-403, DOI: 10.1002/ joc.2081.

Dragotă, C. S., Diumitrașcu, M., Grigorescu, I., Kucsicsa, G., 2011: The Climatic Water Deficit in South Oltenia Using the Thornthwaite Method, Forum geografic. Studii şi cercetări de geografie şi protecția mediului 10 (1), 140-148, DOI: 10.5775/fg.2067-4635.2011.032.i. 
Emberger, L., 1930: Sur une formule applicable en géographie botanique, Comptes rendus hebdomadaires des séances de l'Académie des Sciences 191, 389-390.

Emberger, L., 1933: Nouvelle contribution à l'étude de la classification des groupements végétaux, Revue générale de botanique 14, 1-145.

Emberger, L., 1954: Projet d'une classification des climates, du point de vue phytogéographique. Bulletin de la Société d'bistoire naturelle de Toulouse 78, 159-180.

Gavilán, R. G., 2005: The use of climatic parameters and indices in vegetation distribution. A case study in the Spanish Sistema Central. International Journal of Biometeorology 50, 111-120, DOI: 10.1007/s00484-005-0271-5.

Hrnjak, I., Lukić, T., Gavrilov, M. B., Marković, S. B., Unkašević, M., Tošić I., 2014: Aridity in Vojvodina, Serbia, Theoretical and Applied Climatology 115, 323-332, DOI: 10.1007/s00704-0130893-1.

IPCC, 2014: Climate Change 2014: Synthesis Report. Contribution of Working Groups I, II and III to the Fifth Assessment Report of the Intergovernmental Panel on Climate Change [Core Writing Team, R.K. Pachauri and L.A. Meyer (eds.)], IPCC, Geneva.

Kazadjiev, V., Moteva, M., Georgieva, V., 2012: Near and Far Future Hydro-Thermal Tendencies for Crop Growing in Bulgaria, Sixteenth International Water Technology Conference, IWTC, Istanbul, Turkey. http://iwtc.info/wp-content/uploads/2012/06/G149.pdf (23.03.2017).

Kenawy, A. M., McCabe, M. F., Vicente-Serrano, S. M., Robaa, S. M., Lopez-Moreno, J. I., 2016: Recent changes in continentality and aridity conditions over the Middle East and North Africa region, and their association with circulation patterns, Climate Research 69, 25-43, DOI: 10.3354/ cr01389.

Klein Tank, A. M. G., Wijngaard, J. B., Können, G.P. K., Böhm, R. B., Demarée, G., Gocheva, A., Mileta, M., Pashiardis, S., Hejkrlik, L., Kern-Hansen, C., Heino, R., Bessemoulin, P., Müller-Westermeier, G. M., Tzanakou, M., Szalai, S., Pálsdóttir, T. P., Fitzgerald, D., Rubin, S., Capaldo, M., Maugeri, M., Leitass, A., Bukantis, A., Aberfeld, R., Van Engelen, A. F. V., Forland, E., Mietus, M., Coelho,
F., Mares, C., Razuvaev, V., Nieplova, E., Cegnar, T., Antonio López, J. L., Dahlström, B., Moberg, A., Kirchhofer, W. Ceylan, A., Pachaliuk, O., Alexander, L. V. and Petrovic, P., 2002: Daily dataset of $20^{\text {th }}$ century surface air temperature and precipitation series for the European Climate Assessment, International Journal of Climatology 22, 1441-1453, DOI: 10.1002/joc.773.

Kwiatkowski, C. A., 2015: Yield and Quality of Chamomile (Chamomilla recutita (L.) Rausch.) Raw Material Depending on Selected Foliar Sprays and Plant Spacing, ACTA Scientiarum Polonorum: Hortorum Cultus 14 (1), 143-156.

Lappas, I., Tsioumas, V., Zorapas, V., Kaloumenos, K., 2014: Estimation and Surface Distribution of Climate Indices in the Water District of Central - Eastern Greece, $10^{\text {th }}$ International Hydrogeological Congress of Greece, Thessaloniki, 397-406 (31.03.2017).

Leblois, A., Quirion, P., 2013: Review: Agricultural insurances based on meteorological indices: Realization, methods and research challenges, Meteorological Applications 20, 1-9, DOI: 10.1002/ met.303.

Maliva, R., Missimer, T., 2012: Arid Lands Water Evaluation and Management, Environmental Science and Engineering, Springer-Verlag, Berlin, Heidelberg, DOI: 10.1007/978-3-642-29104-3_2

Melkonyan, A., Asadoorian, M. A., 2014: Climate impact on agroeconomy in semiarid region of Armenia, Environment, Development and Sustainability 16 (2), 393-414, DOI: 10.1007/s10668013-9483-8.

Moteva, M., Kazandjiev, V., Georgieva, N., 2010: Climate Change and the Hydrothermal and Evapotranspiration Conditions in the Planning Regions of Bulgaria, Fourteenth International Water Technology Conference, IWTC 14 2010, Cairo, Egypt. http://www.iwtc info/2010_pdf/01-01.pdf (04.04.2017)

Nistor, M. M., 2016: Spatial distribution of climate indices in the Emilia-Romagna region, Meteorological Applications 23, 304-313, DOI: 10.1002/met.1555.

Nikolova, N., Mochurova, M., 2012 Changes in Air Temperature and Precipitation and Impact on Agriculture, Forum geographic 11 (1), 81-89, DOI: 10.5775/fg.2067-4635.2012.044.i.
Păltineanu, C., Mihailescu, I. F., Seceleanu, I., Dragotă, C., Vasenciuc, F., 2007: Using aridity indexes to describe some climate and soil features in Eastern Europe: a Romanian case study, Theoretical and Applied Climatology 90, 263-274, DOI: 10.1007/s00704-007-0295-3.

Peptenatu, D., Sorodoev, I., Prăvălie, R. 2013: Quantification of the aridity process in South-Western Romania, Journal of Environmental Health Science E Engineering 11 (3), https://link.springer. com/article/10.1186/2052-336X-11-5 (18.03.2017).

Pelin, L. I., 2016: Drought Assessment in the Moldavian Plain, PESD 10 (1), 161169, DOI: 10.1515/pesd-2016-0014.

Rego, C. F., Rocha, M. S., 2014: Climatic patterns in the Mediterranean Region, Ecologia Mediterranea 40 (1), 49-59.

Riazanova, A. A., Voropay, N. N., Okladnikov, I. G., Gordov, E. P., 2016: Development of computational module of regional aridity for web-GIS "Climate", Earth and Environmental Science 48, 241-247, DOI: 10.1088/17551315/48/1/012032.

Rivas-Martinez, S., 1981: Les étages bioclimatiques de la végétation de la péninsule Ibérique. Anales del Jardín Botánico de Madrid 37 (2), 251-268.

Sajjad, H., Shahzada, A., 2014: Classification and Assessment of Aridity over Pakistan Provinces (1960-2009), International Journal of Environment 3 (4), 24-35, DOI: http://dx.doi.org/10.3126/ ije.v3i4.11728.

Salnikov, V., Kozhahmetov, P., Abugalieva, A., Turulina, G., Tazhibayeva, T., Polyakova, S., 2016: Grain Yield as an Indicator of the Drought in Kazakhstan, $4^{\text {th }}$ International Geography Symposium - GEOMED 2016, May 23 - 26, 2016, Kemer, Antalya, Turkey, 68-79.

Savo, V., De Zuliani, E., Salvati, L., Perini, L., Caneva, G., 2012: Long-Term Changes in Precipitation and Temperature Patterns and Their Possible Impacts on Vegetation (Tolfa-Cerite Area, Central Italy), Applied Ecology and Environmental Research 10 (3), 243-266, DOI: 10.15666/aeer/1003_246266.

Selyaninov, G. T., 1930: Methods of agricultural climatology (in Russian), Agricultural Meteorology $22 \mathrm{~L}$.

Selyaninov, G. T, 1958: The nature and dynamics of the droughts. In Droughts in the
A. Ş Vlăduţ N. Nikolova M. Licurici

\section{Aridity assessment within southern \\ Romania and northern Bulgaria}

Procjena aridnosti za južnu Rumunjsku i sjevernu Bugarsku 
HRVATSKI

GEOGRAFSKI

GLASNIK

79/2,5-26 (2017.)
USSR, their Nature, Recurrences and Impact on Crops Yields (in Russian), Gidrometeoizdat, Leningrad.

Tiscovschi, A., Manea, G., Cocoș, O., Vijulie, I., Cuculici, R., 2013: Characteristics of Aridity Conditions in South Dobrudja, Riscuri și Catastrofe 12 (1), 57-65.

Topliisky, D., 2006: Drought in Bulgaria
Based on Thornthweite's Classification Scheme. Proceedings of Second International Scientific Conference Global Changes and Nerw Challenges of 21 Century, 2223 April, Sofia.

Zmudzka, E., 2004: The Climatic Background of Agricultural Production in Poland (1951- 2000), Miscellanea Geographica 11, 127-137.
Wilhite, D. A., 2000: Drought as a natural hazard: Concepts and definitions, in: Wilhite, D. A. (Ed.): Drought: A Global Assessment, Routledge, London and New York, 3-8.

Zambakas, J., 1992: General Climatology, Department of Geology, National \& Kapodistrian University of Athens: Athens, Greece.
Sources

Izvori

Climate data for cities worldwide, https://en.climate-data.org (20.02.2017)

Desserts of the World - USGS, https://pubs.usgs.gov/gip/deserts/what/world.html (19.02.2017)

European Climate Assessment \& Dataset, http://www.ecad.eu (15.02.2017)

Global climate data, http://www.en.tutiempo.net (24.02.2017)

Monthly de Martonne Aridity Index - NTUA, http://hoa.ntua.gr/contours/monthlyidm (23.02.2017)

Pearson's Correlation Coefficient - Statistics Solutions, http://www.statisticssolutions.com/pearsons-correlation-coefficient (31.03.2017)

Authors Autori
Alina Ştefania Vlăduț_： vladut_alina2005@yahoo.com PhD, Associate Profesor, University of Craiova, Faculty of Sciences, Geography Department, Str. I. I. Cuza, no. 13, Craiova, 200585 Dolj, Romania

Nina Nikolova nina@gea.uni-sofia.bg PhD, Associate Profesor, 2St. Kliment Ohridski University of Sofia, Faculty of Geology and Geography, Tsar Osvoboditel Blvd. 15, 1504 Sofia, Bulgaria

Mihaela Licurici mihaela_licurici@yahoo.com PhD, Lecturer, University of Craiova, Faculty of Sciences, Geography Department, Str. I. I. Cuza, no. 13, Craiova, 200585 Dolj, Romania 